\title{
40. BACTERIAL BIOMASS AND ACTIVITY PROFILES WITHIN DEEP SEDIMENT LAYERS1
}

\author{
B. A. Cragg, ${ }^{2,3}$ R. J. Parkes, ${ }^{2,3}$ J. C. Fry,${ }^{3}$ R. A. Herbert, ${ }^{4}$ J.W.T. Wimpenny, ${ }^{3}$ and J. M. Getliff ${ }^{3}$
}

\begin{abstract}
Microbiological examination of sediment cores from the Peru margin (Leg 112) has produced highly significant results: (1) bacteria were present at all sediment depths sampled to 80 meters below seafloor (mbsf); (2) Bacteria were observed in the process of cell division at all but one depth to $80 \mathrm{mbsf}$; (3) Viable bacteria of different types (heterotrophs, sulfate-reducing, nitrate-reducing, methanogenic, and hydrocarbon oxidizing) have been isolated from many of the sediment samples, including those at $80 \mathrm{mbsf}$; and (4) Potential activity rates for sulfate reduction and methanogenesis have been determined and are consistent with the distribution of the respective bacteria and in-situ chemical profiles within the sediment. In combination, these results unequivocally demonstrate the presence and activity of bacteria within deep sediment layers.
\end{abstract}

\section{INTRODUCTION}

Sediment microorganisms, especially bacteria, play a dominant role in the mineralization of sedimenting organic matter. This activity has a profound effect on both the organic and inorganic chemistry of the sediment and thus on mineral and fossil formation. Bacterial activity also affects the oil generation characteristics of the sediment. Most of the research about sediment microbiology has concentrated on the surface few meters. These studies demonstrated the close involvement of bacteria in diagenetic processes and mineral formation, some of which were initially thought to be purely chemical processes (e.g., pyrite formation, manganese and iron cycling). Such studies also demonstrated that although bacterial activity is concentrated near the sediment surface, significant activity continues with increasing depth. The type of bacterial activity also changes as sediment depth increases (Parkes and Taylor, 1985). Indirect geochemical evidence suggests that microbial activity continues to considerable depth within sediments (e.g., chemical changes in pore water, gas production, modification of organic complexes, such as kerogen, concretion formation and isotopic evidence; Krumbein, 1983). The thermal gradient of the Earth's crust is approximately $10^{\circ}$ to $40^{\circ} \mathrm{C} \mathrm{km}^{-1}$, and bacteria grow at temperatures in excess of $100^{\circ} \mathrm{C}$ at elevated pressure (Jannasch and Taylor, 1984). Thus, it is unlikely that bacteria would be inhibited by elevated temperatures until several kilometers below the Earth's surface. Microbiological studies of deep sediment layers present considerable difficulties. These include the prevention of contamination from the more active surface layers, and the provision of both realistic enrichment conditions for bacterial isolation and realistic incubation conditions for activity measurements. There have been a few reports of the detection or cultivation of bacteria from sediments to depths of $200 \mathrm{~m}$ (Davis, 1967; Oremland et al., 1982; Belyaev and Ivanov, 1983; Bianchi, 1986), but isolation does not demonstrate in-situ activity and there are always concerns regarding contamination. Recently, positive indication of low levels of anaerobic bacterial activity

\footnotetext{
${ }^{1}$ Suess, E., von Huene, R., et al., 1990. Proc. ODP, Sci. Results, 112: College Station, TX (Ocean Drilling Program).

2 Scottish Marine Biological Association, P.O. Box 3, Oban, Argyll PA34 $4 \mathrm{AD}$, United Kingdom. New address: Dept. of Geology, University of Bristol, Bristol BS8 1RJ, United Kingdom.

${ }^{3}$ Dept. of Pure and Applied Biology, Univ. of Wales College of Cardiff, P.O. Box 915, Cardiff CF1 3TL, United Kingdom.

4 Dept. of Biology, Univ. of Dundee, Dundee DD1 4HN, United Kingdom.
}

have been found from between 4 and $167 \mathrm{~m}$ in subsurface sediments, this included both sulfate-reduction and methanogenesis (Whelan et al., 1985; Tarafa et al., 1987). We report here the results of a comprehensive microbiological investigation of sediment samples down to 80 mbsf at two sites of Leg 112 .

\section{MATERIALS AND METHODS}

\section{Shipboard Handling}

Sediment and pore-water samples were removed from sections of Holes $680 \mathrm{C}$ and $681 \mathrm{C}$ by three procedures (Suess, von Huene, et al., 1986):

1. Cores for bacterial enrichment and activity estimation were treated as follows. Whole-round portions of a core (10 cm long, approximately $300 \mathrm{~cm}^{3}$ ) were cut from the core sections (Table 1) with sterile (alcohol-washed) apparatus. The samples were capped and nitrogen was flushed through the end caps, which were then sealed with tape and paraffin wax. These were then sealed in metal cans adapted to allow for flushing with nitrogen prior to storage at $5^{\circ} \mathrm{C}$.

2. Samples for direct microscopic observation (1-2 $\left.\mathrm{cm}^{3}\right)$ were taken from the cut end of the section immediately after removal of the $10-\mathrm{cm}$ core sample These were stored in $20 \mathrm{~mL}$ of $5 \%$ formalin solution $(250 \mathrm{~mL}$ IAPSO standard seawater to which had been added $30 \mathrm{~mL}$ formalin [Fisher formaldehyde solution vol/vol containing $10 \%-15 \% \mathrm{vol} / \mathrm{vol}$ methanol]) at $5^{\circ} \mathrm{C}$.

3. Whole-round cores adjoining or near the $10 \mathrm{~cm}$ for microbiological examination were squeezed for interstitial water. These samples were treated as follows: (1) $4 \mathrm{~mL}$ was added to $1 \mathrm{~mL}$ of $10 \%$ mercury acetate, mixed, and stored refrigerated for sulfate analysis; (2) $2 \mathrm{~mL}$ was frozen for nitrate analysis. Holes $680 \mathrm{C}$ and $681 \mathrm{C}$ were drilled on the 6 and 8 November 1986, respectively, and samples were stored refrigerated until they were opened for microbiological examination from 12 January 1987.

\section{Laboratory Handling}

\section{Intact Sediment Samples}

\section{Handling}

All primary handling was conducted at $16^{\circ} \mathrm{C}$ under a sterile nitrogen jet using sterile (autoclaved) apparatus and aseptic techniques. The sample caps were removed and both exposed surfaces briefly flamed. The sample was split into $2-\times 5-\mathrm{cm}$ 
Table 1. Detailed list of Leg 112 samples provided for bacteriological examination.

\begin{tabular}{|c|c|}
\hline $\begin{array}{l}\text { Core, sample, } \\
\text { interval }(\mathrm{cm})\end{array}$ & $\begin{array}{l}\text { Depth } \\
\text { (mbsf) }\end{array}$ \\
\hline \multicolumn{2}{|c|}{$\begin{array}{c}\text { Hole } 680 \mathrm{C} \\
\text { Position: } 11^{\circ} 03.90^{\prime} \mathrm{S}, 78^{\circ} 04.67^{\prime} \mathrm{W} \\
\text { Water Depth: } 252.5 \mathrm{~m}\end{array}$} \\
\hline $\begin{array}{l}112-680 \mathrm{C}-1 \mathrm{H}-1,120-130 \\
-1 \mathrm{H}-2,20-30 \\
-1 \mathrm{H}-2,50-60 \\
-1 \mathrm{H}-2,100-110 \\
-1 \mathrm{H}-4,30-40 \\
-2 \mathrm{H}-3,30-40\end{array}$ & $\begin{array}{l}1.20 \\
1.70 \\
2.00 \\
2.50 \\
4.80 \\
9.10\end{array}$ \\
\hline \multicolumn{2}{|c|}{$\begin{array}{c}\text { Hole } 681 \mathrm{C} \\
\text { Position: } 10^{\circ} 58.60^{\prime} \mathrm{S}, 77^{\circ} 57.46^{\prime} \mathrm{W} \\
\text { Water Depth: } 150.5 \mathrm{~m}\end{array}$} \\
\hline $\begin{array}{c}112-681 \mathrm{C}-1 \mathrm{H}-2,0-19 \\
-1 \mathrm{H}-2,20-30 \\
-1 \mathrm{H}-2,50-60 \\
-1 \mathrm{H}-2,100-110 \\
-1 \mathrm{H}-3,30-40 \\
-1 \mathrm{H}-4,30-40 \\
-2 \mathrm{H}-2,30-40 \\
-4 \mathrm{H}-2,30-40 \\
-5 \mathrm{H}-3,30-40 \\
-7 \mathrm{H}-2,30-40 \\
-8 \mathrm{H}-2,30-40 \\
-9 \mathrm{H}-6,30-40\end{array}$ & $\begin{array}{r}1.50 \\
1.70 \\
2.00 \\
2.50 \\
3.30 \\
4.80 \\
7.70 \\
26.70 \\
36.20 \\
55.20 \\
64.70 \\
80.20\end{array}$ \\
\hline
\end{tabular}

sections by extruding the top $5 \mathrm{~cm}$ into a polycarbonate sleeve $(5 \mathrm{~cm})$ and cutting with a sterile blade. Small subcores were taken from both sections using 5 -mL plastic syringes (Beckton-Dickinson, Oxford, U.K.) from which the luer end had been removed. Volumes taken were $1 \times 6 \mathrm{~cm}^{3}$ and $1 \times 5 \mathrm{~cm}^{3}$ for bacterial enrichment, $28 \times 5 \mathrm{~cm}^{3}$ for bacterial activity measurements, $1 \times 5 \mathrm{~cm}^{3}$ for wet/dry ratios and organic carbon determinations, and $1 \times 1 \mathrm{~cm}^{3}$ for isolation of ammonifying bacteria. Syringes were sealed with butyl rubber "Suba Seals" (Wm. Freeman and Co. Ltd., Barnsley, U.K.) and stored for a few hours (MPN) or overnight (activity measurements) in anaerobic jars under nitrogen at $16^{\circ} \mathrm{C}$.

\section{Bacterial Counts}

A most-probable-number (MPN) technique (Colwell, 1979) was used to estimate bacterial numbers. This involved five, or more usually seven, dilution levels starting with pure sediment and descending serially by triplicate 1:5 dilutions.

\section{Preparation of MPN Vials}

All MPN enrichments were performed in 7-mL hypovials sealed with butyl rubber septa and aluminum caps (Pierce and Warriner, Chester, U.K.), except for the enrichment of hydrocarbon oxidizers, which were grown in $30-\mathrm{mL}$ hypovials similarly sealed but with a plastic center well (Burkard Scientific, Uxbridge, U.K.) suspended from a drilled hole in the septa. Vials destined for detection of nitrate utilizers contained an inverted durham tube for gas collection. Hypovials used for the dilution series were 70 $\mathrm{mL}$ by volume.

Vials were initially prepared with three evacuation and gassing cycles. This was done through a hypodermic needle, between approximately -1 bar and +2 bar, using $\mathrm{N}_{2}$, $\mathrm{N}_{2}(90 \%) / \mathrm{CO}_{2}(10 \%)$ or $\mathrm{H}_{2}(80 \%) / \mathrm{CO}_{2}(20 \%)$ mixtures dependent on the medium (see below) and finally leaving the vials evacuated. They were then autoclaved at $1.05 \mathrm{~kg} \mathrm{~cm}^{-2}$ for 15 $\min$.

\section{Dispensing System}

The medium dispensing system consisted of a $10-\mathrm{mL}$ glass syringe fitted with a plastic stopcock (Gallenkamp, Glasgow, U.K.). The plunger was removed and the open end sealed with a rubber stopper penetrated by two $1.6-\mathrm{mm}$ steel tubes. This allowed a throughput of gas that maintained a positive pressure in the syringe when the outlet tube was clamped. A glass pipette tip also penetrated the rubber stopper to allow for delivery of media under pressure. Evacuated vials were filled with $5 \mathrm{~mL}$ of medium and gas to slightly above ambient pressure. Vials for the dilution series received $20 \mathrm{~mL}$ of medium by the same procedure. The tops of the septa were smeared with a silicone rubber sealant to prevent leakage through the pierced septum. Those used for detecting lactate utilizing sulfate-reducing bacteria (SRB) were not smeared with sealant because the acetate present in the sealant might have interfered with the medium.

\section{Preparation of Media}

All media contained $\mathrm{NaCl}$ and $\mathrm{MgCl}_{2}$ in quantities approximating in situ salinities; Hole $680 \mathrm{C}=28$ and $4.2 \mathrm{~g} / \mathrm{dm}^{3}$, Hole $681 \mathrm{C}=32$ and $5 \mathrm{~g} / \mathrm{dm}^{3}$, respectively. Additionally resazurin (1 $\mathrm{mL}$ of $0.1 \%$ solution per liter) was added as an oxygen detector. The $\mathrm{pH}$ was adjusted to 7.5 with $1 \mathrm{M} \mathrm{HCl}$ and $2 \mathrm{M}$ $\mathrm{Na}_{2} \mathrm{CO}_{3}$ prior to dispensing (Pfennig et al., 1981).

Postgate B medium (Postgate, 1979) was used for the detection of SRB. Sodium lactate $\left(3.5 \mathrm{~g} / \mathrm{dm}^{3}\right)$ or sodium acetate (anhydrous; $1.8 \mathrm{~g} / \mathrm{dm}^{3}$ ) were used to differentiate between lactate and acetate utilizers. Carbon dioxide-saturated sodium bicarbonate $(30 \mathrm{~mL})$ was added after autoclaving. The medium was dispensed under $\mathrm{N}_{2} / \mathrm{CO}_{2}$.

Nitrate-respiring organisms were enriched in a medium of nutrient broth $\left(13 \mathrm{~g} / \mathrm{dm}^{3}\right)$ and $\mathrm{KNO}_{3}\left(1.01 \mathrm{~g} / \mathrm{dm}^{3}\right)$ dispensed under $\mathrm{N}_{2}$.

Viable heterotrophs were grown in Widdel's marine medium (Pfennig et al., 1981), with the following alterations; $\mathrm{Na}_{2} \mathrm{SO}_{4}$ was omitted from solution 1 , and casamino acids $(0.5$ $\left.\mathrm{g} / \mathrm{dm}^{3}\right)$ and yeast extract $\left(0.1 \mathrm{~g} / \mathrm{dm}^{3}\right)$ added. After autoclaving, solution 2 was modified according to Pfennig and Biebl (1981), but without EDTA added. Solutions 4, 5, and 7a through 7d were added as normal. Solution 3 was modified by the addition of $\mathrm{NaWO}_{4} \cdot 2 \mathrm{H}_{2} \mathrm{O}\left(4 \mathrm{mg} / \mathrm{dm}^{3}\right)$ and a supplementary vitamin solution $\left(1 \mathrm{~mL} / \mathrm{dm}^{3}\right.$; folic acid $2 \mathrm{mg}$, pyridoxine $10 \mathrm{mg}$, riboflavin $5 \mathrm{mg}$, nicotinic acid $5 \mathrm{mg}$, calcium pantothenate 5 $\mathrm{mg}$, lipoic acid $\left.5 \mathrm{mg}, \mathrm{H}_{2} \mathrm{O} 100 \mathrm{~mL}\right)$ was added. Glucose $(0.49$ $\left.\mathrm{g} / \mathrm{dm}^{3}\right)$ and glycerol $\left(0.4 \mathrm{~mL} / \mathrm{dm}^{3}\right)$, dissolved together in $5 \mathrm{~mL}$ of distilled water and autoclaved, were the final additions. Solutions 6,8 , and 9 were omitted. This medium was dispensed under $\mathrm{N}_{2} / \mathrm{CO}_{2}$.

The medium for hydrocarbon oxidizers was basically similar except that in solution $1, \mathrm{Na}_{2} \mathrm{SO}_{4}$ was not omitted and casamino acids, yeast extract, glucose, and glycerol were not added. Solution 6a (sodium acetate) was added at double strength $(30 \mathrm{mM})$ and the medium was dispensed as described above. The vials were then uncapped in a sterile anaerobic cabinet (Forma Scientific, Haverhill, U.K.) and a paper disk containing radio-labeled ${ }^{14} \mathrm{C}$-hexadecane was added to each vial prior to resealing. These were $5 \mathrm{~mm}$ autoclaved filter paper discs that had been spotted with $1 \mu \mathrm{L}$ of hexadecane solution $(50 \mu \mathrm{Ci}$ hexadecane $[61 \mathrm{mCi} \mathrm{mM}$, Amersham International, Amersham, U.K. in $500 \mu \mathrm{L}$ hexane) in a sterile laminar flow cabinet under ionizing ultraviolet light. This gave approximately $0.1 \mu \mathrm{Ci}$ per disk (Somerville et al., 1985).

Methanogenic bacteria were enriched in a medium based on that for viable heterotrophs. Alterations were: solution 1 contained $\mathrm{Na}_{2} \mathrm{SO}_{4}\left(0.15 \mathrm{~g} / \mathrm{dm}^{3}\right)$ and cysteine- $\mathrm{HCl}\left(0.3 \mathrm{~g} / \mathrm{dm}^{3}\right)$ 
but casamino acids were omitted. After autoclaving, solution $6 \mathrm{a}\left(3 \mathrm{~mL} / \mathrm{dm}^{3}\right.$ double strength $\left.=9 \mathrm{mM}\right)$ and filter sterilized methylamine $\left(2 \mathrm{~mL} / \mathrm{dm}^{3}\right.$ of $0.338 \mathrm{~g} / \mathrm{mL}$ solution $\left.=10 \mathrm{mM}\right)$ were added. Glucose and glycerol were omitted. Solution 2 was modified by increasing concentrations of three constituents- $\mathrm{CoCl}_{2} \cdot 6 \mathrm{H}_{2} \mathrm{O}\left(0.24 \mathrm{~g} / \mathrm{dm}^{3}\right), \mathrm{Na}_{2} \mathrm{MoO}_{4} \cdot 2 \mathrm{H}_{2} \mathrm{O}\left(0.24 \mathrm{~g} / \mathrm{dm}^{3}\right)$ and $\mathrm{NiCl}_{2} \cdot 6 \mathrm{H}_{2} \mathrm{O}\left(1.19 \mathrm{~g} / \mathrm{dm}^{3}\right)$. This medium was dispensed under $\mathrm{H}_{2} / \mathrm{CO}_{2}$.

The diluent was prepared similarly to the medium for viable heterotrophs but without casamino acids, yeast extract, glucose, and glycerol and was dispensed under $\mathrm{N}_{2} / \mathrm{CO}_{2}$.

Ammonifying bacteria were enriched using an MPN tube technique (Alexander, 1965) with Crossley Milk Medium (Oxoid, Basingstoke, U.K.) supplemented with $3 \% \mathrm{wt} / \mathrm{vol}$ $\mathrm{NaCl}$.

All media were dispensed several weeks prior to inoculation, and any vials not reduced (pink color due to oxidized resazurin) were discarded.

\section{Inoculation and Incubation Procedures}

Initial manipulations were performed in an anaerobic cabinet that had been sterilized by swabbing with an antiseptic (Aseptopol 250. Brentchem, London, U.K.) and then with absolute ethanol, followed by $1 \mathrm{hr}$ under an ionizing ultraviolet light. One $5-\mathrm{mL}$ syringe of sediment was ejected into the first diluent vial, which was mixed and successively diluted (5 $\mathrm{mL}$ in $20 \mathrm{~mL}$ ). All $20 \mathrm{~mL}$ of the sediment dilutions were withdrawn and injected, in 1-mL aliquots, into the triplicate vials for each medium. An additional number of vials prepared for assessing hydrocarbon oxidizers were left uninoculated as controls in subsequent analysis. A single vial was used for the zero dilution level. This was performed by extruding $1 \mathrm{~cm}^{3}$ of sediment sequentially from the $1-\times 6-\mathrm{cm}^{3}$ syringe into each of the six different media in $7-\mathrm{mL}$ vials. All vials, apart from those containing Postgate B + lactate were again smeared with sealant. Incubation was at $16^{\circ} \mathrm{C}$ and vials were checked weekly for growth.

Presumptive growth was detected by media-blackening for SRB, acid and/or gas production for nitrate reducers, turbidity and direct counting for viable heterotrophs, headspace methane for methanogens, and ${ }^{14} \mathrm{CO}_{2}$ evolution for hydrocarbon oxidizers. Viable counts and confidence limits were calculated according to Hurley and Roscoe (1983). All vials demonstrating positive growth were subcultured and stored at $-70^{\circ} \mathrm{C}$ in a cryoprotectant solution (Hippe, 1984). Any vials that became oxidized after inoculation were not included in the MPN calculations.

\section{Detection of Methane}

Headspace gases were analyzed by gas chromatography (Parkes and Taylor, 1985). Vials were repressurized to 2 bar with $\mathrm{H}_{2} / \mathrm{CO}_{2}$ and resmeared with sealant before incubation was resumed.

\section{Detection of Hydrocarbon Oxidation}

Sulfuric acid $(0.5 \mathrm{~mL}$ of $0.05 \mathrm{M})$ was added to the vials and mixed. $\beta$-Phenylethylamine $(0.3 \mathrm{~mL}$; Sigma, Poole, U.K.) was introduced into the center wells and the vials left overnight. The wells were removed and placed in $10 \mathrm{~mL}$ of scintillant $(800 \mathrm{~mL}$ toluene, $70 \mathrm{~mL}$ phenylethylamine, $80 \mathrm{~mL}$ methanol, $5 \mathrm{~g}$ PPO $0.1 \mathrm{~g}$ POPOP). The filter paper disk and $0.1 \mathrm{~mL}$ of the medium were separately added to $10 \mathrm{~mL}$ of Instagel scintillant (Packard, Caversham, U.K.) to assess residual activity. Counting was performed for $4 \mathrm{~min}$ in a Rackbeta liquid scintillation counter (Pharmacia-LKB, Milton Keynes, U.K.) with external standard and quench correction.

\section{Detection of Nitrate Reduction}

Removal of nitrate from the medium and the presence/ absence of nitrite was assessed with a nitrate reduction test (Cruikshank et al., 1975), and the presence/absence of ammonium was determined with an indophenol blue colorimetric test (Golterman et al., 1978).

\section{Potential Activity Measurements}

\section{Sample Handling}

Four isotopes were separately injected into the syringe cores along their center line while slowly withdrawing the needle. One syringe-core was immediately autoclaved as a control, and another six incubated at $16^{\circ} \mathrm{C}$ in pairs for 3,10 , and 20 days. After incubation all samples were stored at $-20^{\circ} \mathrm{C}$ until analyzed.

\section{Isotope Preparation}

All isotopes were obtained from Amersham International (Amersham, U.K.). They were suitably diluted with sterile distilled water and membrane filter sterilized $(0.2-\mu \mathrm{m}$ pore size). Injections into syringe-cores were: ${ }^{32} \mathrm{PO} 35 \mu \mathrm{L}=6.2 \times$ $10^{7} \mathrm{DPM} ;{ }^{35} \mathrm{SO}_{4} 2 \mu \mathrm{L}=4.4 \times 10^{6} \mathrm{DPM} ; \mathrm{H}^{14} \mathrm{CO}_{3} 25 \mu \mathrm{L}=3.4$ $\times 10^{6} \mathrm{DPM} ; \mathrm{K}^{15} \mathrm{NO}_{3} 25 \mu \mathrm{L}\left(20 \mathrm{mg} / \mathrm{mL}\right.$ solution of $\left.98.7 \%{ }^{15} \mathrm{~N}\right)$.

\section{Measurements of Activity}

Incorporation of inorganic phosphate into phospholipids was determined by a chloroform extraction procedure (Moriarty et al., 1985), followed by counting ${ }^{32} \mathrm{P}$ in a liquid scintillation counter.

Sulfate reduction activity was estimated following a distillation procedure that allowed for separate calculation of acid-volatile-sulfide and pyrite + sulfur (Parkes and Buckingham, 1986). Methanogenic activity was calculated from the amount of ${ }^{14} \mathrm{CH}_{4}$ produced; this was stripped from the sediment with nitrogen (flow $250 \mathrm{~cm}^{3} / \mathrm{min}$ ), oxidized to ${ }^{14} \mathrm{CO}_{2}$ in a $\mathrm{CuO}$ furnace (Carbolite, Sheffield, U.K.), and the ${ }^{14} \mathrm{CO}_{2}$ trapped and counted by liquid scintillation (Whelan et al., 1985). The trapping system of Whelan et al. (1985) was modified by replacing the three cold traps with one containing methanol at $-20^{\circ} \mathrm{C}$. In addition, a series of three sequential scintillation vials was used to ensure collection of all of the ${ }^{14} \mathrm{CO}_{2}$. Recovery of ${ }^{14} \mathrm{CH}_{4}$ standards was typically $95 \%$ to $99 \%$ using this system. Estimates of nitrate reduction activity were obtained by mass spectrography (Macfarlane and Herbert, 1984). Daily label turnover rates were independently calculated from 3,10 , and 20 day samples, after subtraction of any DPM counts obtained from the respective control subcores (sulfate reduction DPM $=193$; methanogenesis DPM $=47$ ). $\mathrm{A}$ mean label turnover rate was then obtained and multiplied by the in-situ pool size of the relevant compound (Suess, von Huene, et al., 1986) to obtain potential activity rates.

\section{Direct Microscopic Observation}

Acridine orange staining and microscopic observation followed the general recommendations of Fry (1988).

Fixed samples were vortex mixed and 10 to $100 \mu \mathrm{L}$ added to $10 \mathrm{~mL}$ of filter sterilized artificial seawater. This diluted sediment was stained with a final concentration of $5 \mathrm{mg} / \mathrm{dm}^{3}$ of acridine orange and filtered through an Irgalan black stained membrane filter $(25 \mathrm{~mm} ; 0.2 \mu \mathrm{m}$ pore size). The filter was rinsed with $12.5 \mathrm{~mL}$ of citric acid buffer and mounted in a minimum of paraffin oil under a cover slip. The filter sterilized artificial seawater contained $\mathrm{NaCl}(27.4), \quad \mathrm{KCl}(0.77)$, $\mathrm{MgCl}_{2}(11.21), \mathrm{NaHCO}_{3}(0.202)$, and $\mathrm{CaCl}_{2}\left(2.4 \mathrm{~g} / \mathrm{dm}^{3}\right)$. The ingredients were dissolved in the order stated in $2 \%$ formal- 


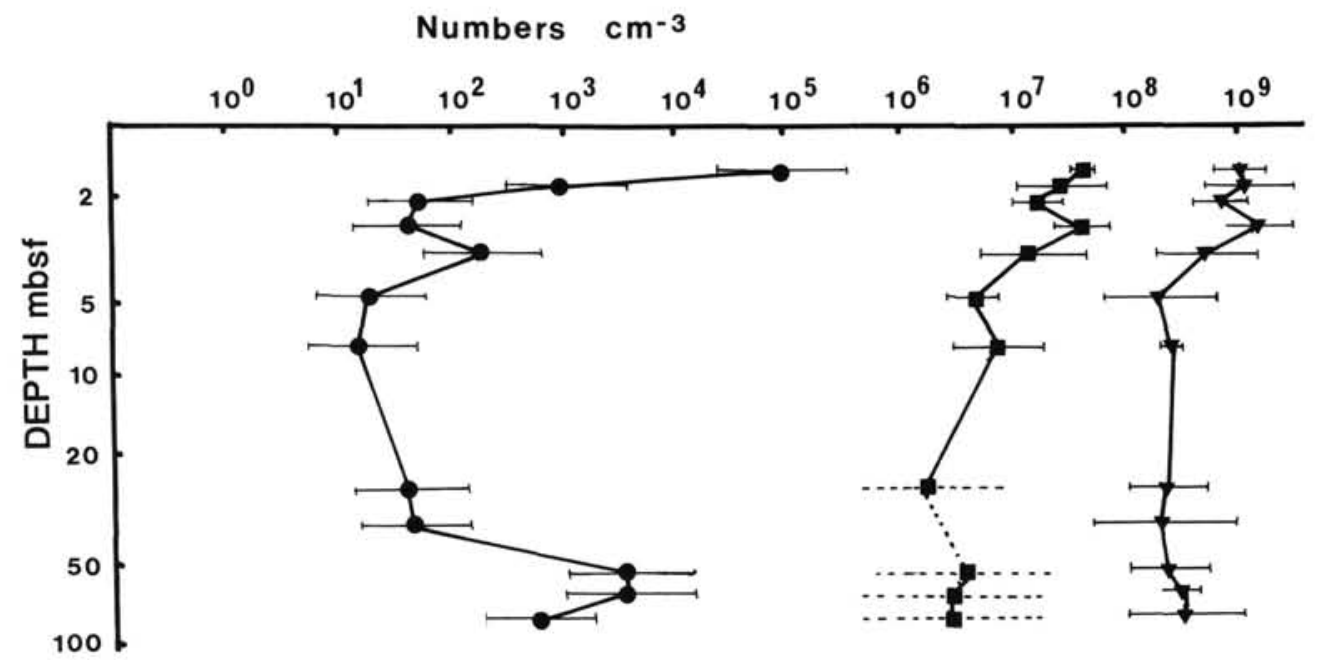

Figure 1. Depth distribution of anaerobic viable heterotrophs (MPN) (-), numbers of dividing cells (-D), and direct count $(\boldsymbol{\nabla}-\mathbf{\nabla})$, with $95 \%$ confidence limits, in Hole 681C. (Dashed confidence limits indicate limits that are too large to include without reducing clarity, dashed section of the dividing cell profile indicates an omitted data value of zero.)

dehyde made up in filter-sterilized deionized water. The citric acid buffer was pH 3.0 and consisted of $100 \mathrm{~mL}$ of $21 \mathrm{~g} / \mathrm{dm}^{3}$ citric acid and $59 \mathrm{~mL}$ of $4 \mathrm{~g} / \mathrm{dm}^{3} \mathrm{NaOH}$ (Pettipher, 1983) made up in filter-sterilized deionized water.

The mounted membrane filters were viewed under incident illumination with a Zeiss Standard microscope fitted with the following: a 50-W mercury vapor lamp, a wide-band interference filter set for blue excitation, a $100 \times$ (numerical aperture $=1.32$ ) Leitz Fluotar objective lens and $8 X$ eyepieces. Bacterially shaped, green and red fluorescing objects were counted. Cells that were on or off particles of sediment were scored separately. The volume of sediment used was that which gave about $50 \%$ coverage of sediment particles on the filter. Dividing cells were also counted; these were either bacteria with a clear invagination or pairs of cells of identical morphology. The total number of cells and the number of dividing cells were calculated from the sum of double the number on-particles plus the number off-particles. This procedure estimated the cells obscured by sediment particles. The frequency of dividing cells was the ratio of the number of dividing bacteria to the total number of bacteria $\times 100$. All numbers were calculated per unit dry weight and converted later to counts per cubic centimeter (wet). Dry weights of sediment were obtained from the fixed samples dried at $80^{\circ} \mathrm{C}$ until constant weight on membrane filters.

\section{RESULTS}

Data have been obtained from identical work on Holes $681 \mathrm{C}$ and $680 \mathrm{C}$; however, as samples were obtained from much greater depths for Hole 681C, this "Results" section and the following discussion are based principally on this core, with data from Hole $680 \mathrm{C}$ used for comparison.

\section{Direct counts}

Bacteria were present at all depths to $80 \mathrm{mbsf}$ (Fig. 1). Direct counts exhibited a gradual logarithmic decline in numbers from $1.05 \times 10^{9} / \mathrm{cm}^{3}$ at $1.5 \mathrm{~m}$ to $3.12 \times 10^{8} / \mathrm{cm}^{3}$ at $80.2 \mathrm{~m}$, representing a 3.4-fold decrease. All but one sample investigated showed evidence of cell division (Figs. 1 and 2). Numbers of dividing cells had a steep 15 -fold decrease with depth from a value of $4.97 \times 10^{7} / \mathrm{cm}^{3}$ at $1.5 \mathrm{~m}$ to $3.35 \times 10^{6} / \mathrm{cm}^{3}$ at $80.2 \mathrm{~m}$. The frequency of dividing cells (FDC) decreased more gradually than the absolute count of dividing cells from

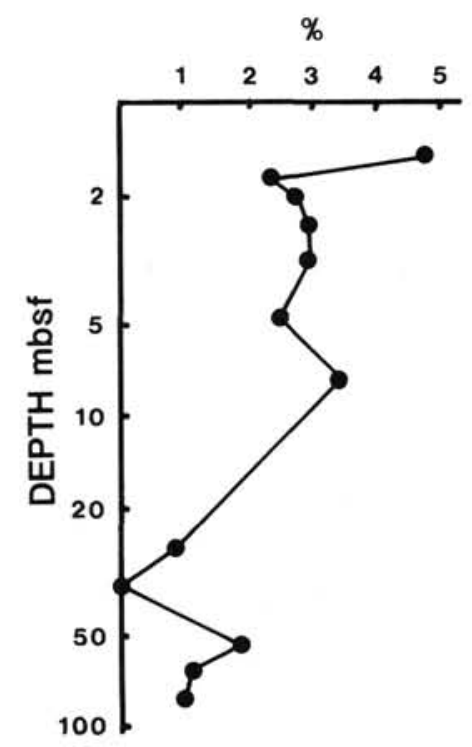

Figure 2. Depth distribution of frequency of dividing cells (FDC) in Hole 681C.

$4.7 \%$ at $1.5 \mathrm{~m}$ to $1.07 \%$ at $80.2 \mathrm{~m}$ (Fig. 2). Nevertheless, a similar pattern was observed in both profiles. Observed bacterial cells were not dividing at one depth $(36.2 \mathrm{~m})$, and this coincided with a minimum in the direct count $\left(2.00 \times 10^{8} / \mathrm{cm}^{3}\right)$. Another measurement of bacterial productivity, based on the incorporation of ${ }^{32} \mathrm{P}$ phosphate into phospholipids showed a similar profile to FDC and dividing cells. However, the full analysis has not been completed; hence, data are not presented.

\section{Viable Counts}

Viable anaerobic heterotrophs demonstrated a steep logarithmic decline in numbers between 1.5 and $2.0 \mathrm{~m}$ from 88,000 cells $/ \mathrm{cm}^{3}$ to 55 cells $/ \mathrm{cm}^{3}$, representing a 1600 -fold decrease (Fig. 1). At 55.2 and $64.7 \mathrm{~m}$, there was a significant $(\mathrm{p}<0.01)$ increase in bacteria to 3553 bacteria/ $\mathrm{cm}^{3}$, followed by a decrease at $80.2 \mathrm{~m}$. The nitrate-reducing bacteria also showed 


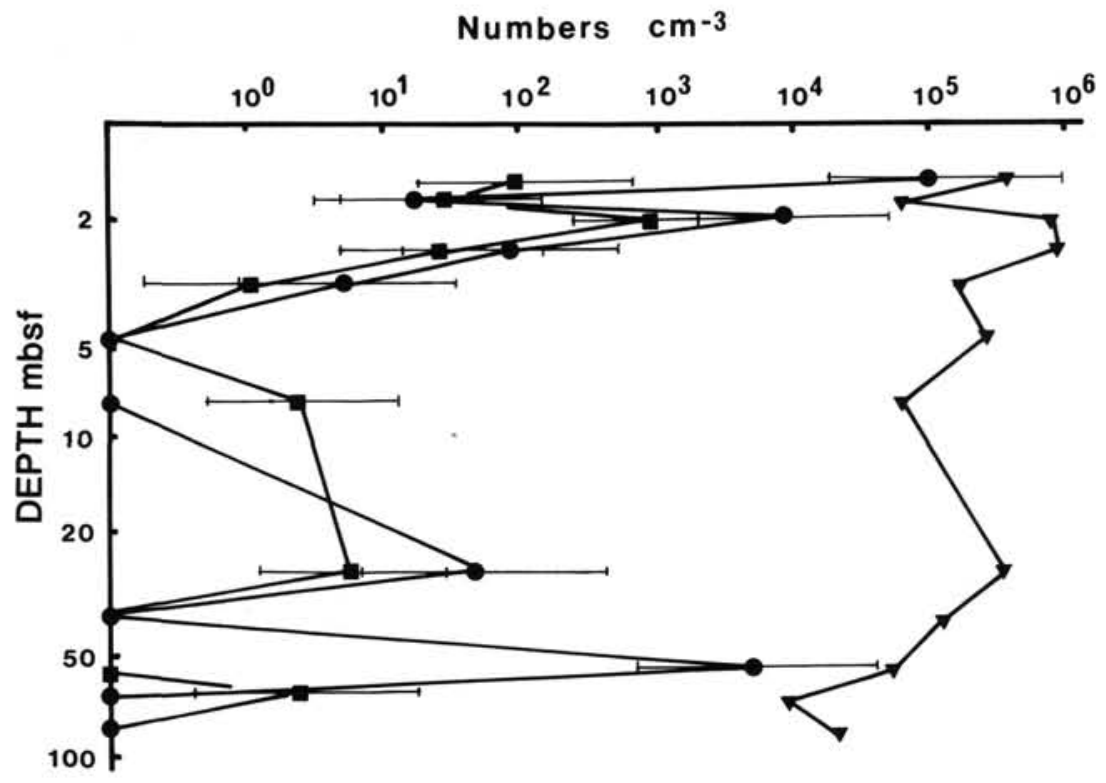

Figure 3. Depth distribution of MPN counts of total nitrate utilizers (-), ammonium producers (- with $95 \%$ confidence limits, and aerobic ammonifying bacteria $(\boldsymbol{\nabla}-\nabla)$ in Hole $681 \mathrm{C}$.

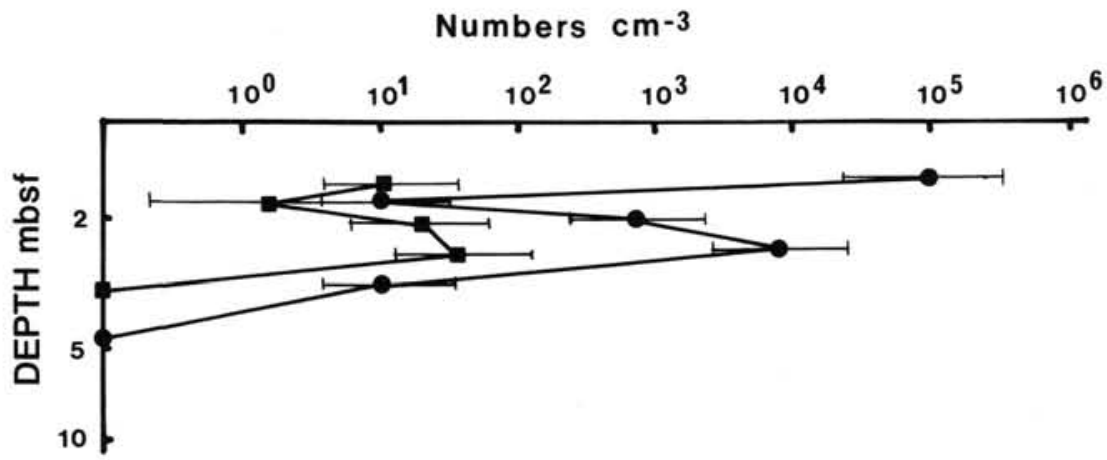

Figure 4. Depth distribution of MPN counts of sulfate-reducing bacteria (SRB), utilizing lactate (-) and acetate (- with $95 \%$ confidence limits, in Hole 681C.

a steep logarithmic decline in numbers, from 140,000 cells $/ \mathrm{cm}^{3}$ at $1.5 \mathrm{~m}$ to zero at $4.8 \mathrm{~m}$ (Fig. 3). This decline was not smooth, however, as a significant increase $(\mathrm{p}<0.05)$ in numbers was observed at $2.0 \mathrm{~m}$. After a minimum between 4.8 and $7.7 \mathrm{~m}$, nitrate-reducing bacteria had a similar profile to anaerobic heterotrophs, with a fluctuating increase to a peak at $55.2 \mathrm{~m}$ $\left(5600\right.$ cells $\left./ \mathrm{cm}^{3}\right)$.

The nitrate-reducing bacteria were able to mediate different reactions, some reduce nitrate to nitrogen and others reduce nitrate to ammonium (Fig. 3). These bacteria are frequently facultative anaerobic heterotrophs and, hence, similar to the anaerobic heterotrophic bacteria; thus, it is not surprising that both bacterial groups have similar depth profiles (Figs. 1 and 3). Those nitrate utilizers that produce ammonium, generally follow the trends in total nitrate utilizers (Fig. 3), although on average they represented less than $1 \%$ of the total nitrate utilizers. The aerobic ammonifying bacteria (Fig. 3) were dominated by sporeforming cells, and while they were numerically the most important bacterial group involved in nitrogen metabolism, it is not known whether they occurred in the sediment samples as vegetative cells or inactive spores. These bacteria exhibited a slow logarithmic, approximately 20 -fold, decrease down to $80 \mathrm{~m}$.
The numbers remained considerably higher than all the other viable counts, which indicated that they were probably present in the sediment as spores.

SRB were found only in the surface $4.8 \mathrm{~m}$ (Fig. 4). Lactate-utilizing SRB were quantitatively more important than those utilizing acetate, which accounted for less than $0.1 \%$ of the total SRB count. Both acetate- and lactateutilizing SRB had essentially the same depth profile, with an initial sharp decline $(1.5-1.7 \mathrm{~m})$, followed by a significant increase $(\mathrm{p}<0.05)$ at 2.0 to $2.5 \mathrm{~m}$ (acetate 28 -fold and lactate 750 -fold) before declining rapidly to zero. Methanogenic bacteria proved difficult to culture and required subculturing twice from the enrichment bottles before their presence could be detected by methane gas production. They also required 18 months incubation. Despite the very low numbers (Fig. 5, maximum counts were 18.7 cells $/ \mathrm{cm}^{3}$ at $1.5 \mathrm{~m}$ ), important differences were observed down the profile. In common with other viable counts, thefe was an initial sharp decline in numbers, followed by a gradual increase to a peak at $2.5 \mathrm{~m}$ of 12.4 cells $/ \mathrm{cm}^{3}$. An elevated count was maintained unti1 $4.8 \mathrm{~m}$, after which methanogens were found in only one isolated sample at $55.2 \mathrm{~m}$, with 3.4 cells $/ \mathrm{cm}^{3}$. 


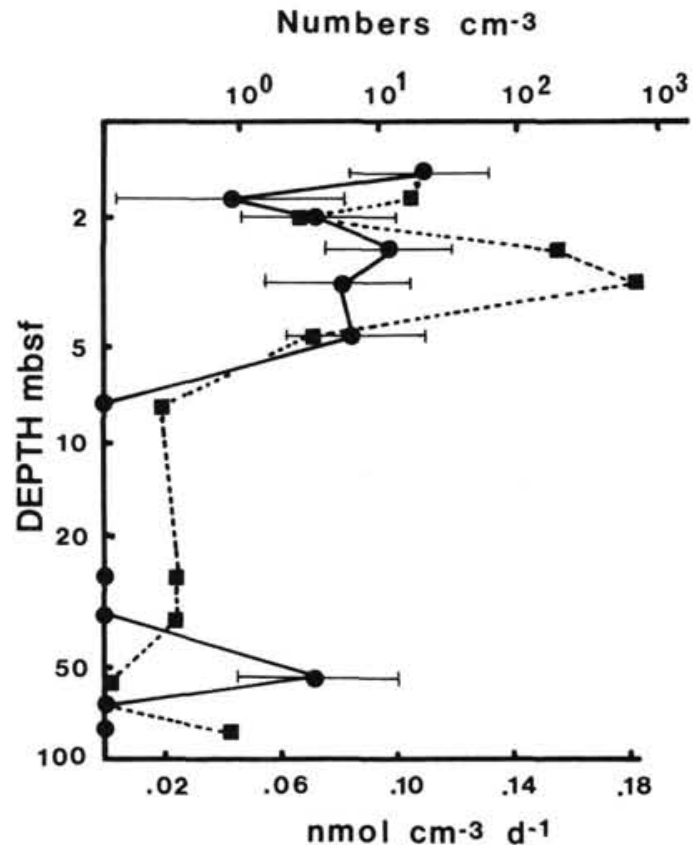

Figure 5. Depth distribution of methanogenic bacteria (MPN) (- - ), with $95 \%$ confidence limits and potential methanogenic activity rates (‥ - in Hole 681C.

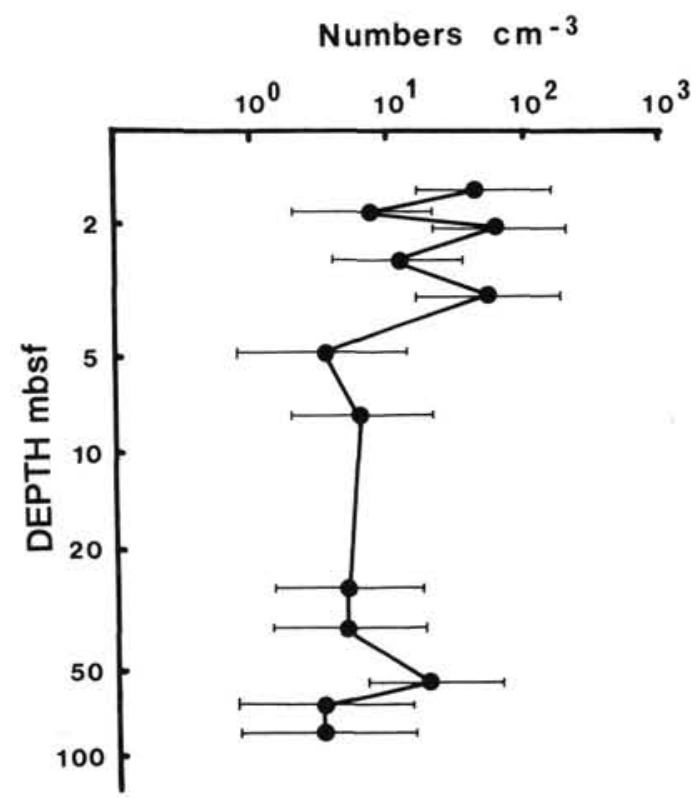

Figure 6. Depth distribution of MPN counts of hydrocarbon (hexadecane) oxidizing bacteria, with $95 \%$ confidence limits, in Hole $681 \mathrm{C}$.

Anaerobic enrichment in the presence of ${ }^{14} \mathrm{C}$-labeled hexadecane resulted in significant production of ${ }^{14} \mathrm{CO}_{2}$ in all samples, although the estimated numbers of hydrocarbon oxidizers were very small (Fig. 6). Like the methanogens, long incubation periods were required (15 months) before positive results were obtained. Despite these low numbers, the depth profile of hydrocarbon-oxidizing bacteria is similar to the profile of other bacterial groups (e.g., Fig. 1), with lowest numbers recorded after $4 \mathrm{~m}$ and with a slight, nonsignificant increase at $55.2 \mathrm{~m}$. The hexadecane may only be incompletely oxidized, and as it is a short-chain hydrocarbon, these results cannot be used directly to indicate the potential degradation of longer-chain hydrocarbons.

The types of anaerobic bacteria identified through the various enrichment techniques represent, in general, mutually exclusive groups, which when added together provide an estimate of the total culturable anaerobic count (Table 2). This figure, when expressed as a percentage of the total direct count, provides a measure of the viability of the anaerobic bacteria. These values are very low $(0.03 \%-0.0000087 \%)$ and cover a wide range (approximately 3500 -fold). Highest ratios were observed at the top of the core $(1.5$ and $2.0 \mathrm{~m})$ and near the base $(55.2$ and $64.7 \mathrm{~m})$.

When the viable count of the different bacterial groups is expressed as a percentage of the total culturable anaerobic count (Table 2), the data suggest a successional pattern in the dominant bacterial groups with sediment depth. Heterotrophs, nitrate utilizers, and lactate-utilizing SRB were dominant components of the culturable anaerobic bacterial population at $1.5 \mathrm{~m}$. However, at $2.0 \mathrm{~m}$ the nitrate reducers alone were prominent, accounting for $92.2 \%$ of the total culturable anaerobic count. By $2.5 \mathrm{~m}$, the SRB had become the principal components of the population, representing more than $98 \%$ of all anaerobic bacteria cultured at this depth. Below this, the methanogenic bacteria became, for the first time, a significant component (e.g., $23.6 \%$ at $4.8 \mathrm{~m}$ ). Hydrocarbon oxidizers contributed significantly to the population in the middle section of the core between $3.3 \mathrm{~m}$ and $36.2 \mathrm{~m}$, at and below the peak in numbers of methanogens. In the deepest samples (36.2 to $80.2 \mathrm{~m}$ ), the heterotrophs and nitrate utilizers again were dominant.

\section{Potential Activities}

Rates of activity obtained in this study should be regarded as potential because we are, as yet, unable to assess the effects of core storage on activity. Incubations were done at the in-situ temperature, but were not conducted at the in-situ pressure.

Sulfate reduction occurred primarily in the upper $4 \mathrm{~m}$ of the core (Fig. 7). Pyrite-volatile-sulfide (PVS) increased to a peak at $1.7 \mathrm{~m}$, with a rate of $0.26 \mathrm{nmol} / \mathrm{cm}^{3} / \mathrm{d}$ and acid-volatilesulfide (AVS) was maximal at $2.0 \mathrm{~m}$, with a rate of 0.34 $\mathrm{nmol} / \mathrm{cm}^{3} / \mathrm{d}$. Together these resulted in a broad peak of total sulfate reduction between 1.7 and $2.5 \mathrm{~m}$ of approximately 0.48 $\mathrm{nmol} / \mathrm{cm}^{3} / \mathrm{d}$. After this, both AVS and PVS decreased rapidly and by $7.7 \mathrm{~m}$ no activity was detectable. Toward the base of the core, sulfate reduction was again observed. Rates were considerably lower (PVS: $0.0011 \mathrm{nmol} / \mathrm{cm}^{3} / \mathrm{d}$ at $55.2 \mathrm{~m}$ and AVS: $0.0016 \mathrm{nmol} / \mathrm{cm}^{3} / \mathrm{d}$ at $64.7 \mathrm{~m}$ ) than in the upper part of the core.

Methanogenesis from $\mathrm{CO}_{2} / \mathrm{H}_{2}$ was present between 1.5 and $2.0 \mathrm{~m}$ (Fig. 5) at a rate of $0.115 \mathrm{nmol} / \mathrm{cm}^{3} / \mathrm{d}$, decreasing to a local minimum of $0.077 \mathrm{nmol} / \mathrm{cm}^{3} / \mathrm{d}$, which coincided with the maximum sulfate reduction rate (Fig. 7). Below this, methanogenesis increased significantly to a maximum of 0.182 $\mathrm{nmol} / \mathrm{cm}^{3} / \mathrm{d}$ at $3.3 \mathrm{~m}$, where sulfate reduction activity was very low. Activity then declined rapidly, reaching a minimum of $0.0023 \mathrm{nmol} / \mathrm{cm}^{3} / \mathrm{d}$ at $64.7 \mathrm{~m}$. At $80.2 \mathrm{~m}$ the rate was elevated to $0.046 \mathrm{nmol} / \mathrm{cm}^{3} / \mathrm{d}$, which is immediately below a local maximum in the AVS rate (Fig. 7).

It is unlikely that nitrate would be present in these anoxic samples, and pore water analysis revealed very low, unreliable, positive nitrate values. Therefore, unlike the other activity data, these results are presented as rates of label turnover (Fig. 8). Nitrate reduction occurred principally in the upper $3 \mathrm{~m}$ of the core (Fig. 8), where denitrification was quantitatively much more important than ammonium production. Potential denitrification decreased to zero at $3.3 \mathrm{~m}$ before 


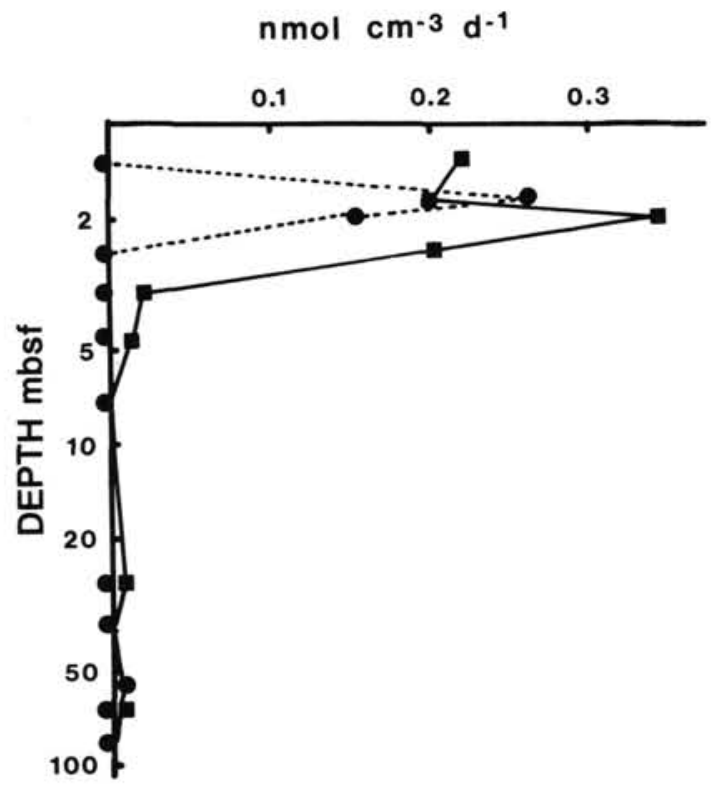

Figure 7. Depth distribution of potential sulfate reduction rates; pyrite + sulfur (- - $\bullet$ ), and acid-volatile sulfide ( $681 \mathrm{C}$.

demonstrating a broad band of activity between 26.7 and 55.2 $\mathrm{m}$. The potential ammonium production profile was more constant with depth; however, it also exhibited a similar broad band of activity to denitrification at 26.7 to $55.2 \mathrm{~m}$. In addition, it is clear that the dominance of denitrification over ammonium production apparent in the upper zone of the core was reversed in the lower sediment layers. As previously mentioned, nitrate-reducing bacteria are often facultative anaerobic heterotrophs; hence, this potential nitrate-reducing activity is most appropriately interpreted as indicating the activity of heterotrophic bacteria, which is supported by the significant $(r=0.73, p<0.01)$, positive relationship between potential nitrate reduction and total culturable anaerobic count.

\section{Hole 680C}

Overall, there is broad agreement between these data and those from Hole $681 \mathrm{C}$, both in terms of biomass and in activity changes with depth, but comparison between the cores is restricted as Hole $680 \mathrm{C}$ was only $9.1 \mathrm{~m}$ deep.

\section{Direct Counts}

Direct counts were similar in numbers to those observed in Hole 681C; however, there was no obvious decline in numbers with depth (Fig. 9A). The mean direct count for all six samples was approximately $7.8 \times 10^{8} / \mathrm{cm}^{3}$. Cell division was observed in all samples; dividing cells did not change with depth. The profile of FDC differed from the other profiles as a decrease with depth was apparent (Fig. 9B). Preliminary data for phospholipid turnover rates (data not shown) broadly agree with both FDC and numbers of dividing cells, although rates were two to three times lower than in Hole 681C.

\section{Viable Counts}

The numbers of anaerobic heterotrophic bacteria in the upper layers of Hole $680 \mathrm{C}$ were similar to the those in Hole 681C (Fig. 9A; Hole 681C number $10^{5} / \mathrm{cm}^{3}$ at $1.5 \mathrm{~m}$ and Hole $680 \mathrm{C}$ number $10^{5} / \mathrm{cm}^{3}$ at $1.7 \mathrm{~m}$ ); however, the subsequent decrease in Hole $680 \mathrm{C}$ was much slower, with only a 40 -fold reduction in numbers by $9.1 \mathrm{~m}$. Both total nitrate-reducing bacteria and nitrate reducers producing ammonia have a

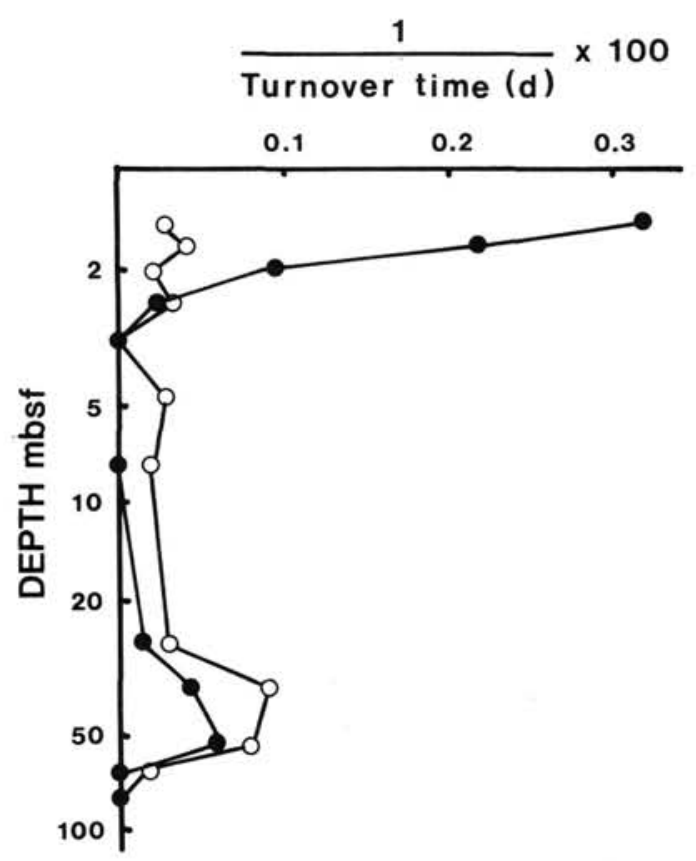

Figure 8. Depth distribution of general heterotrophic potential as expressed by nitrate-reduction turnover times; denitrification (and ammonium production $\left(\mathrm{O}^{-} \mathrm{O}\right)$ in Hole $681 \mathrm{C}$.

similar profile to that at Hole $681 \mathrm{C}$, but numbers are generally lower and the decrease in numbers less sharp (Fig. 9C). The profile of the aerobic ammonifying bacteria was almost identical in both holes. The depth profile of sulfate-reducing bacteria was similar to that in Hole $681 \mathrm{C}$, with an initial decrease in numbers, an increase at about $2 \mathrm{~m}$ (significant, $\mathrm{p}<0.05$ for lactate utilizers), then a decline to zero by $4.8 \mathrm{~m}$ (Fig. 9D). Acetate utilizers were present at essentially the same level as in Hole 681C; however, numbers of lactate utilizers were substantially lower and were approximately equal to the numbers of acetate utilizers. Methanogens were found in only three samples between 2.0 and $4.8 \mathrm{~m}$ (Fig. 9E); this was equivalent to the broad peak observed in Hole 681C. This peak in numbers of methanogens overlapped with the 2-m peak in SRB, but continued to $9.1 \mathrm{~m}$, long after the SRB had reached zero. The numbers of hexadecane oxidizing bacteria were constant, with depth at approximately $9 / \mathrm{cm}^{3}$ (Fig. 9F), the slight increase was not significant.

The successional changes in the types of viable bacteria suggested by data for Hole $681 \mathrm{C}$ also were evident in Hole $680 \mathrm{C}$ data (Table 2). Viable heterotrophs and nitrate utilizers are dominant throughout the hole, but SRB exhibit local maxima at $2.0 \mathrm{~m}$ (acetate) and from 2.0 to $2.5 \mathrm{~m}$ (lactate), with methanogens accounting for a low, but reasonably constant, proportion of the count between 2.0 and $4.8 \mathrm{~m}$. Generally, the proportion of the direct count attributed to total culturable anaerobic cells was greater than in Hole 681C (mean = $0.0098 \%$ ), and the range of a 99 -fold difference between maximum and minimum percentages was considerably lower.

\section{Potential Activities}

Sulfate-reduction rates demonstrated the same profile as that in Hole 681C (Fig. 9G). In contrast, peak activity (AVS + PVS) at $2.5 \mathrm{~m}$ was $1.64 \mathrm{nmol} / \mathrm{cm}^{3} / \mathrm{d}$, which is 3.3 times higher than in Hole $681 \mathrm{C}$.

The depth profile of methanogenic activity (Fig. 9E), while being broadly similar to Hole $681 \mathrm{C}$, between 1.5 and $9.1 \mathrm{~m}$ had 
Table 2. Viable and direct bacterial counts from Holes $680 \mathrm{C}$ and $681 \mathrm{C}$.

\begin{tabular}{|c|c|c|c|c|c|c|c|c|c|}
\hline \multirow[b]{2}{*}{ Hole } & \multirow[b]{2}{*}{$\begin{array}{l}\text { Depth } \\
\text { (mbsf) }\end{array}$} & \multicolumn{6}{|c|}{ Percentage of total culturable anaerobic count } & \multirow[b]{2}{*}{$\begin{array}{c}\text { Total culturable } \\
\text { anaerobic count } \\
\left(\mathrm{mL}^{-1}\right)\end{array}$} & \multirow[b]{2}{*}{$\begin{array}{l}\text { Total direct count } \\
\left(\mathrm{mL}^{-1}\right)\end{array}$} \\
\hline & & $\begin{array}{c}\text { Viable } \\
\text { heterotrophs }\end{array}$ & $\begin{array}{c}\text { Nitrate } \\
\text { utilizers }\end{array}$ & $\begin{array}{l}\text { Sulfate } \\
\text { reducers } \\
\text { (acetate) }\end{array}$ & $\begin{array}{l}\text { Sulfate } \\
\text { reducers } \\
\text { (lactate) }\end{array}$ & $\begin{array}{l}\text { Methane } \\
\text { producers }\end{array}$ & $\begin{array}{c}\text { Hexadecane } \\
\text { oxidizers }\end{array}$ & & \\
\hline \multirow[t]{12}{*}{$681 \mathrm{C}$} & 1.5 & 27.8 & 44.4 & 0.0040 & 27.8 & 0.0060 & 0.016 & 316,883 & $1.05 \times 10^{9}$ \\
\hline & 1.7 & 96.7 & 1.5 & 0.13 & 1.0 & 0.070 & 0.60 & 1,098 & $1.26 \times 10^{9}$ \\
\hline & 2.0 & 0.48 & 92.2 & 0.18 & 6.5 & 0.030 & 0.60 & 11,498 & $6.38 \times 10^{8}$ \\
\hline & 2.5 & 0.48 & 1.11 & 0.53 & 97.6 & 0.15 & 0.14 & 8,403 & $1.56 \times 10^{9}$ \\
\hline & 3.3 & 71.4 & 2.04 & 0 & 4.10 & 1.77 & 20.7 & 283 & $5.04 \times 10^{8}$ \\
\hline & 4.8 & 65.7 & 0 & 0 & 0 & 23.6 & 11.4 & 28 & $1.99 \times 10^{8}$ \\
\hline & 7.7 & 70.0 & 0 & 0 & 0 & 0 & 30.0 & 22 & $2.53 \times 10^{8}$ \\
\hline & 26.7 & 39.4 & 56.1 & 0 & 0 & 0 & 4.85 & 103 & $2.24 \times 10^{8}$ \\
\hline & 36.2 & 90.8 & 0 & 0 & 0 & 0 & 9.2 & 49 & $2.00 \times 10^{8}$ \\
\hline & 55.2 & 38.7 & 61.0 & 0 & 0 & 0.037 & 0.23 & 9,174 & $2.21 \times 10^{8}$ \\
\hline & 64.7 & 99.9 & 0 & 0 & 0 & 0 & 0.10 & 3,553 & $2.81 \times 10^{8}$ \\
\hline & 80.2 & 99.5 & 0 & 0 & 0 & 0 & 0.50 & 553 & $3.12 \times 10^{8}$ \\
\hline \multirow[t]{6}{*}{$680 \mathrm{C}$} & 1.2 & 52.5 & 46.4 & 0.081 & 0.97 & 0 & 0.025 & 22,846 & $1.222 \times 10^{9}$ \\
\hline & 1.7 & 95.6 & 4.34 & 0.020 & 0.002 & 0 & 0.009 & 92,029 & $1.296 \times 10^{9}$ \\
\hline & 2.0 & 99.4 & 0.53 & 0.045 & 0.028 & 0.015 & 0.007 & 141,686 & $8.466 \times 10^{8}$ \\
\hline & 2.5 & 81.2 & 18.7 & 0.024 & 0.033 & 0.013 & 0.032 & 25,626 & $2.054 \times 10^{8}$ \\
\hline & 4.8 & 7.12 & 92.9 & 0 & 0 & 0.004 & 0.008 & 151,618 & $7.828 \times 10^{8}$ \\
\hline & 9.1 & 99.4 & 0 & 0 & 0 & 0 & 0.60 & 2,201 & $1.120 \times 10^{9}$ \\
\hline
\end{tabular}

Note: Viable anaerobic MPN counts expressed as a percentage of the total culturable anaerobic count in each sample. Figures in bold are referred to in the text.

less pronounced changes with depth. There was a local peak in activity between 2.5 and $4.8 \mathrm{~m}$, below a peak of sulfate reduction (Fig. 9G), although the increase at this depth was small.

\section{DISCUSSION}

Both the direct counts of bacteria (Fig. 1; Table 2) and total culturable anaerobic bacteria (Fig. 10; Table 2) demonstrated an exponential decrease in numbers between 1.5 and $4.8 \mathrm{~m}$ of 5.3 -fold and 11,300-fold, respectively. This type of profile is commonly observed in sediments (Rheinheimer, 1985), although most changes are usually thought to occur in the first $10 \mathrm{~cm}$, while below $100 \mathrm{~cm}$, dramatic changes in numbers are rarely apparent. The coring method employed in collecting these samples did not allow for retrieval of about the surface $1 \mathrm{~m}$ of sediment for microbiological examination; thus, we are unable to speculate on bacterial numbers in the first $100 \mathrm{~cm}$. However, the data indicate that bacteria are present in much greater numbers at depth than was previously thought. In addition, the high and relatively constant numbers of dividing cells over the first $10 \mathrm{~m}$ (Fig. 1), representing approximately $3 \%$ of the direct count (Fig. 2), demonstrate that a proportion of these bacteria are actively growing, not just surviving.

Decreases in bacterial numbers with depth are frequently associated with a time-based reduction in the amount of organic carbon available as an energy source (Nedwell, 1984). Hole $681 \mathrm{C}$ contained on average relatively little organic carbon $($ mean $=3.2 \%$ ), compared with nearby cores from the same leg, and a steady decrease in organic carbon from approximately $5.2 \%$ to $1.7 \%$ was observed in the depth range of 0.4 to $13 \mathrm{~m}$ (Patience et al., this volume). A decrease in this organic carbon would be expected to occur because of sequential hydrolysis and utilization of relatively recalcitrant polymers, such as cellulose, proteins, and chitin, by various bacterial groups (Nedwell, 1984). There is, however, some evidence that at this site variations in organic carbon result principally from differences in influxes of organic carbon at the time of deposition and only secondarily due to depthrelated diagenesis (Patience et al., this volume). From 13 to $80.2 \mathrm{~m}$, both direct counts (Fig. 1) and, more obviously, total culturable anaerobic counts (Fig. 10; Table 2) increased. This is coincident with an increase in organic carbon concentra- tions from approximately $1.7 \%$ to $4 \%$. As organic carbon associated with bacterial biomass was never more than $0.1 \%$ of total organic carbon in this depth interval (data not shown), such increases probably represent depositional change.

The presence of bacteria at $80.2 \mathrm{~m}\left(3.12 \times 10^{8} \mathrm{~cm}^{3}\right.$ direct count, Fig. 1), particularly when a proportion has been shown as viable $\left(553 \mathrm{~cm}^{3}\right.$ total culturable anaerobic count, Fig. 10; Table 2) is in striking contrast to the generally accepted view that bacteria rarely occur in significant numbers below the surface few meters and that deeper sediment layers are devoid of bacterial life. Calculations of FDC (Fig. 2) indicate that a proportion of the bacterial population is actually growing. It seems unlikely that dividing cells have merely survived in this form from the surface sediment layers, as they decrease much faster with sediment depth than the total bacterial count $(4.5$ times faster), and there is no obvious reason why the two-cell forms should have different survival rates. Although FDC can be used to calculate growth rates for pelagic bacteria (Hagström et al., 1979), this cannot be done for these samples as it is known that the procedure greatly overestimates bacterial growth rates in sediments (Newell and Fallon, 1982; Fallon et al., 1983). However, what is clear is that some bacteria are still dividing and are therefore active, even down to $80 \mathrm{mbsf}$.

Comparisons of our data for bacterial populations with previous work is difficult as most bacterial analysis is often confined to samples well within the top $1 \mathrm{~m}$ of sediment. To our knowledge, this is the first report of direct bacterial counts, FDC, and estimates of the numbers of a range of viable bacteria down to $80 \mathrm{~m}$. There have been a few reports of the detection or cultivation of bacteria from sediments 200 $\mathrm{m}$ deep (Davis, 1967; Oremland et al., 1982; Belyaev and Ivanov, 1983; Bianchi, 1986). These results support our more extensive data. Hole $681 \mathrm{C}$ has a direct count of $1.05 \times 10^{9} / \mathrm{cm}^{3}$ at $1.5 \mathrm{~m}$, equivalent to $2.94 \times 10^{9} / \mathrm{g}$ (dry wt). Direct counts of $1.78 \times 10^{10} / \mathrm{g}$ (dry wt) for the top $1 \mathrm{~cm}$ layer have been obtained for a site near Hole 681C (unpubl. data). Rice et al. (1986) reported sediment surface bacterial counts of $1.2 \times$ $10^{10} / \mathrm{g}$ (dry wt) from sediments in the Porcupine Sea Bight in the Northeast Atlantic. Also Lochte and Turley (1988) gave direct counts between $2.2 \times 10^{9}$ and $1.6 \times 10^{11} / \mathrm{g}$ (dry wt) that were associated with phytodetritus on the sediment surface from a deep mid-oceanic area of the Northeast Atlantic. 
Table 2 (continued).

\begin{tabular}{lrrl}
$\begin{array}{l}\text { Anaerobic } \\
\text { culturable/ } \\
\text { direct }(\%)\end{array}$ & $\begin{array}{c}\text { Aerobic } \\
\text { ammonifiers } \\
\left(\mathrm{mL}^{-1}\right)\end{array}$ & $\begin{array}{c}\text { Total culturable } \\
\text { count }\left(\mathrm{mL}^{-1}\right)\end{array}$ & $\begin{array}{c}\text { Total culturable/ } \\
\text { direct }(\%)\end{array}$ \\
\hline 0.030 & 404,600 & 721,483 & 0.069 \\
0.000087 & 60,080 & 61,178 & 0.0048 \\
0.0018 & 845,300 & 856,798 & 0.13 \\
0.00054 & 939,300 & 947,703 & 0.061 \\
0.000056 & 160,400 & 160,682 & 0.032 \\
0.000014 & 281,100 & 281,128 & 0.14 \\
0.0000087 & 66,040 & 66,062 & 0.026 \\
0.000046 & 341,000 & 341,103 & 0.15 \\
0.000025 & 133,600 & 133,649 & 0.067 \\
0.0041 & 55,200 & 64,374 & 0.029 \\
0.0013 & 9,728 & 13,281 & 0.0047 \\
0.00018 & 21,560 & 22,113 & 0.0071 \\
0.0019 & 103,000 & 125,846 & 0.011 \\
0.0071 & 45,520 & 137,549 & 0.011 \\
0.017 & 431,300 & 572,986 & 0.068 \\
0.013 & 266,900 & 292,526 & 0.14 \\
0.019 & 17,970 & 169,588 & 0.022 \\
0.00020 & 28,840 & 31,041 & 0.0028 \\
\hline
\end{tabular}

Compared to these data, the direct bacterial counts at $80.2 \mathrm{~m}$ at Hole $681 \mathrm{C}\left(3.12 \times 10^{8} / \mathrm{cm}^{3}\right)$ represent a significant bacterial population (about $1 \%$ ).

The percentage of the total bacterial population that were culturable was generally low (Table 2). Viability of natural bacterial populations are normally low and vary between $0.0001 \%$ and $10 \%$ of the direct count (van Es and Meyer-Reil, 1982). The viability of bacteria in Hole $681 \mathrm{C}$ down to $2.5 \mathrm{~m}$, as well as from $55.2 \mathrm{~m}$ and deeper, is within the lower end of this range. The central zone of the core $(4.8-36.2 \mathrm{~m})$ particularly had low viability (e.g., $0.0000087 \%$ at $7.7 \mathrm{~m}$ ), but FDC was not significantly lower over much of this depth (Fig. 2). This suggests that these bacteria may have an exceptionally slow growth rate and/or are unable to grow as satisfactorily in the culture media we used as bacteria from other regions. Bacterial activity within this middle zone is also low (Figs. 5 and 7) and is roughly congruent with the area of low organic carbon (Fig. 10; Patience et al., this volume). Hence, bacteria in this region may be limited by available organic matter.

The succession of bacterial types observed down the core (Table 2) is one that is well documented for surface sediments (Hines and Buck, 1982; Jørgensen, 1983; Nedwell, 1984), but it is surprising to see a succession from anaerobic heterotrophs to SRB to methanogens in sediments below $1 \mathrm{~m}$ that have probably been anoxic below the surface few millimeters (Revsbech, et al., 1980). The presence of anaerobic hydrocarbon-oxidizing bacteria in the sediment, even at low levels, is interesting, as it has often been reported that hydrocarbons do not degrade under anoxic conditions (Connan, 1987). These bacteria also increased in relative importance within and below the zone of methanogenesis (Table 2; Figs. 5 and 6) and thus may be active in situ. However, their role and ecological importance remain unclear.

In the absence of oxygen, sulfate is the most important electron acceptor for bacterial activity within marine sediments. Sulfate is present at high concentrations (approx. 16 $\mathrm{mM}$ ) in the top $10 \mathrm{~m}$ of sediment and gradually decreases to zero at $30 \mathrm{~m}$ before rising again at about $80 \mathrm{~m}$ to approximately $35 \mathrm{mM}$ at $190 \mathrm{~m}$ (Fig. 10). This is caused by brine incursion (Suess, von Huene, et a1., 1986). Both sulfate-reduction and SRB were present in the upper portion of Hole 681C (Figs. 4 and 7), which is consistent with the presence of high sulfate concentrations. Maximum potential sulfate reduction rates of 0.464 and $0.491 \mathrm{nmol} / \mathrm{cm}^{3} / \mathrm{d}$ at 1.7 and $2.0 \mathrm{~m}$, respectively
(Figs. 7 and 10), are low. However, these rates are comparable to those at the sediment surface of several inshore marine sites $\left(0.2-2800 \mathrm{nmol} / \mathrm{cm}^{3} / \mathrm{d}\right.$; Senior et al., 1982; Parkes and Taylor, 1985; Parkes and Buckingham, 1986) and also with the rates from continental shelf surface sediments $(0.0001$ to $46 \mathrm{nmol} / \mathrm{cm}^{3} / \mathrm{d}$; Sorokin, 1962; Tsou et al., 1973; Goldhaber and Kaplan, 1975; Jørgensen, 1983; Parkes and Taylor, 1985; Edenborn et al., 1987). The rapid decrease in sulfate-reduction below $2 \mathrm{~m}$ is associated with an increase in methanogenesis to its maximum rate of approximately $0.160 \mathrm{nmol} / \mathrm{cm}^{3} / \mathrm{d}$ between 2.5 and $3.3 \mathrm{~m}$ (Fig. 10). This situation normally would be explained by the ability of SRB to out-compete methanogens for common growth substrates, such as acetate and hydrogen (Kristjanssen et al., 1982; Schönheit et al., 1982; Nedwell, 1984). Hence, sulfate reduction should occur above methanogenesis within a sediment profile. This explanation is not valid in this case, as sulfate is still available $(16 \mathrm{mM}$, Fig. 10) for sulfate reduction; thus, these bacteria should still be able to inhibit methanogenesis by substrate competition. Another possibility is that the metabolic intermediates being produced by the heterotrophic bacteria change from substrates that SRB can use to substrates that are predominantly utilized by methanogens (e.g., methanol, methylamine, and trimethylamine; Oremland and Polcin, 1982; King et al., 1983; Winfrey and Ward, 1983; King, 1984). However, because the increase in methanogenesis resulted from methane production from $\mathrm{H}_{2} / \mathrm{CO}_{2}$, this hypothesis also seems an unlikely explanation.

The rates of methanogenesis at Hole $681 \mathrm{C}$, although low, are comparable to previously published rates. Some reported rates are 0.001 to $0.028 \mathrm{nmol} / \mathrm{cm}^{3} / \mathrm{d}$ in salt-marsh sediments (Senior et al., 1982), 0.01 to $20 \mathrm{nmol} / \mathrm{cm}^{3} / \mathrm{d}$ (depending on substrate) found in the Baltic Sea (Lein et al., 1981). and approximate 1 y 0.2 to $1.0 \mathrm{nmol} / \mathrm{cm}^{3} / \mathrm{d}$, and 0.5 to $1.8 \mathrm{nmol} /$ $\mathrm{cm}^{3} / \mathrm{d}$ obtained from clean and organically enriched sea-loch sites (Parkes and Taylor, 1985). However, maximum rates of methanogenesis were approximately 2.6 times lower than the maximum rate of sulfate reduction.

A significant $(r=0.625, p<0.05)$ positive correlation existed between the viable counts of methanogens and rates of methanogenesis. This suggests that viable counts do reflect real changes in the bacterial populations in situ and are not significantly affected by contamination problems. However, rates of methane production were measured at low levels without positive growth in the enrichment medium (Fig. 5). This reflects the lack of sensitivity of the MPN technique.

Between approximately 6 and $50 \mathrm{~m}$, bacterial activity and the numbers of viable anaerobic bacteria were low, but surprisingly, activity, bacterial direct counts, FDC, and viable counts all increase below this depth (Figs. 1,2, and 10). This increased bacterial activity is associated with a local peak in organic carbon concentrations (Patience et al., this volume) and an increase in sulfate from brine incursion from below 85 $\mathrm{m}$ (Fig 10). The increase in sulfate reduction at about $60 \mathrm{~m}$ was small and probably sulfate-limited. This explains the increase in methanogenesis directly below $(80.2 \mathrm{~m}$, Fig. 10). Just above this methanogenesis is a broad peak in methane gas $(26,000$ $\mu \mathrm{L} / \mathrm{dm}^{3}$ (Suess, von Huene, et al., 1986). The simultaneous increase in activity measurements, direct and viable counts, and independent pore-water methane profiles strongly suggests that contamination was not a problem, even in the deepest samples.

The reasons for the complex and rather unexpected changes in bacterial populations with sediment depth in Hole $681 \mathrm{C}$ are not clear, especially as there are no data from the important surface layers. We postulate, however, that a reasonable explanation can be drawn, based on the results so far available and current concepts of bacterial interactions 


\section{Numbers $\mathrm{cm}^{-3}$}
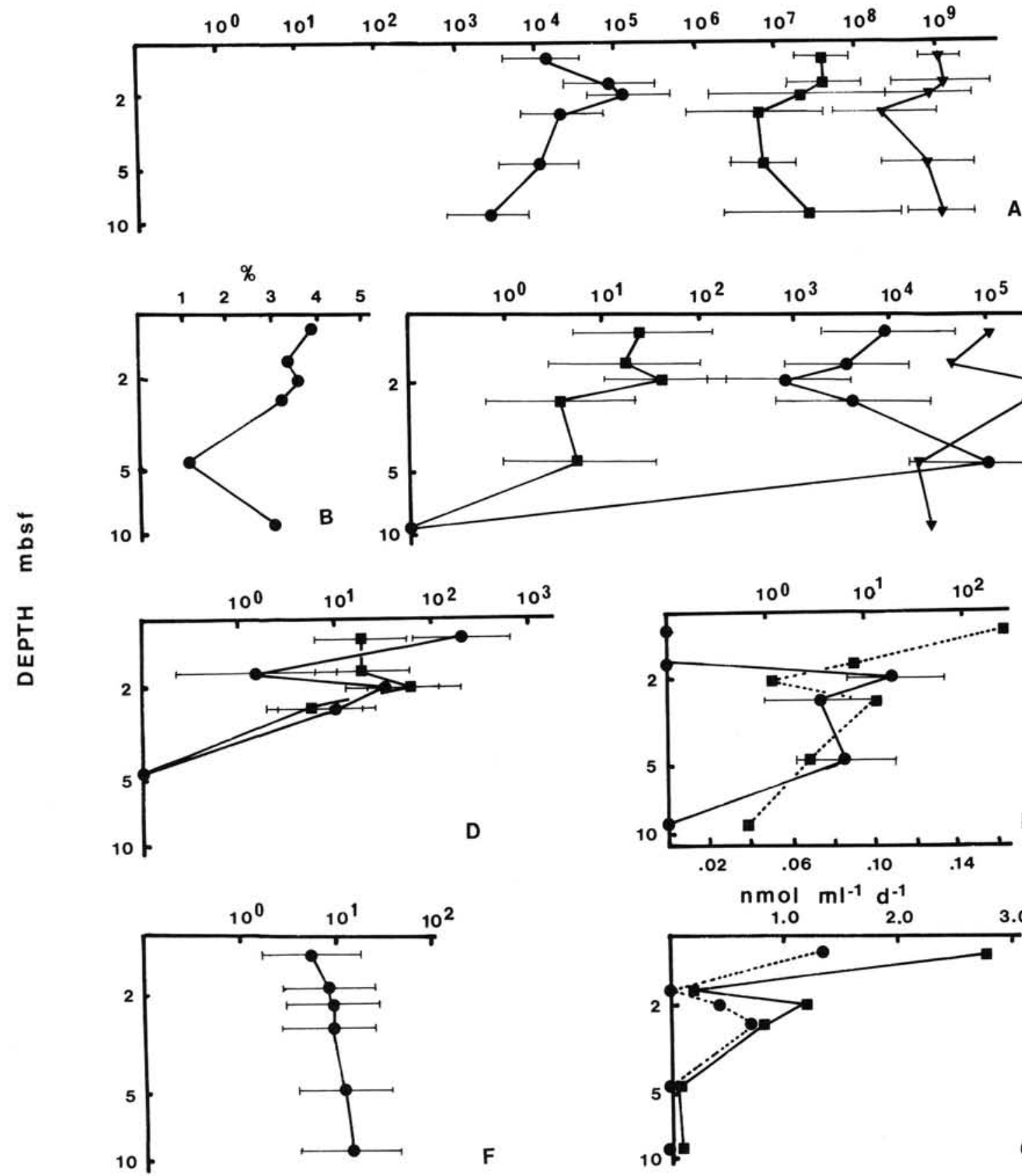

$\mathbf{F}$

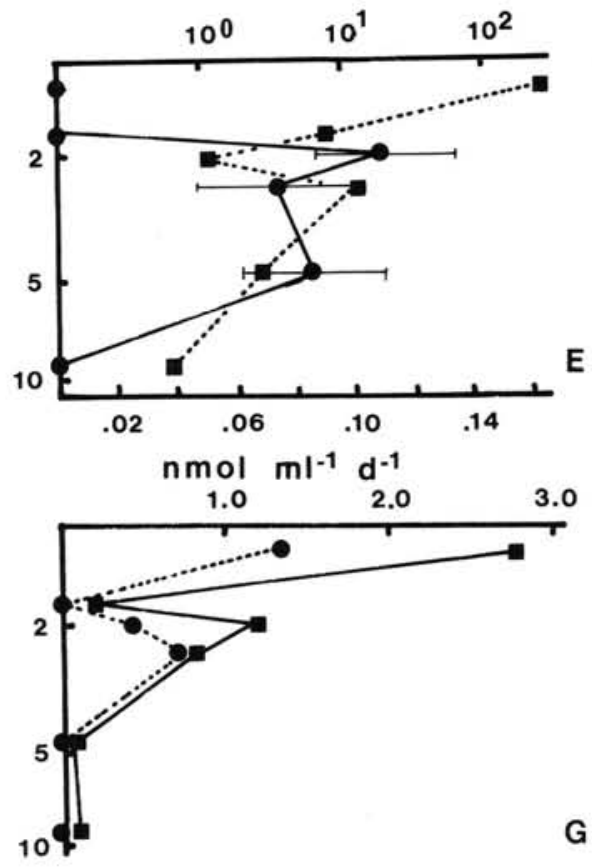

Figure 9. Depth distribution of bacterial counts and activity in Hole 680C. A. Anaerobic viable heterotrophs (MPN), (- numbers of dividing cells ( $-\mathbf{E})$, and direct count $(\boldsymbol{\nabla}-\mathbf{\nabla})$. B. Frequency of Dividing Cells (FDC). C. MPN counts of total nitrate utilizers (-), ammonium producers $(\mathbf{-}-\mathbf{-})$, and aerobic ammonifying bacteria $(\boldsymbol{\nabla}-\boldsymbol{\nabla})$. D. MPN counts of sulfate-reducing bacteria (SRB), utilizing lactate (-), and acetate (- Methanogenic bacterial counts (MPN) (- E. and potential methanogenic activity rates (- - F. MPN counts of hydrocarbon (hexadecane) oxidizing bacteria. G.

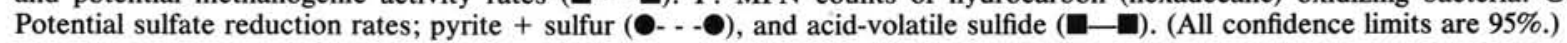

within anaerobic sediments. It seems likely that most of the sulfate reduction was concentrated in the top $15 \mathrm{~cm}$ or so of sediment (e.g., Parkes and Buckingham, 1986) and was decreasing rapidly before our first sample at $1.5 \mathrm{~m}$. At this depth, the bulk of organic carbon readily available to bacteria had probably already been removed, and the heterotrophic bacteria would be using more recalcitrant polymers with a resulting slow rate of carbon degradation and energy liberation. Anaerobic degradation of organic matter characteristically involves a mixed population of bacteria, with either methanogens or
SRB conducting the essential role of terminal oxidizers, which allows for further degradation to proceed (Zeikus, 1983). It may be that when recalcitrant polymers are being degraded, a synergistic coupling of heterotrophic bacteria and methanogens is favored, rather than coupling with the potentially faster-growing SRB. This would explain why sulfate reduction decreased before sulfate depletion, and why there were sufficient substrates for methanogenesis (Fig. 10). If the coupling between heterotrophs and SRB was becoming stressed, this should ultimately be reflected in a decrease in the hetero- 


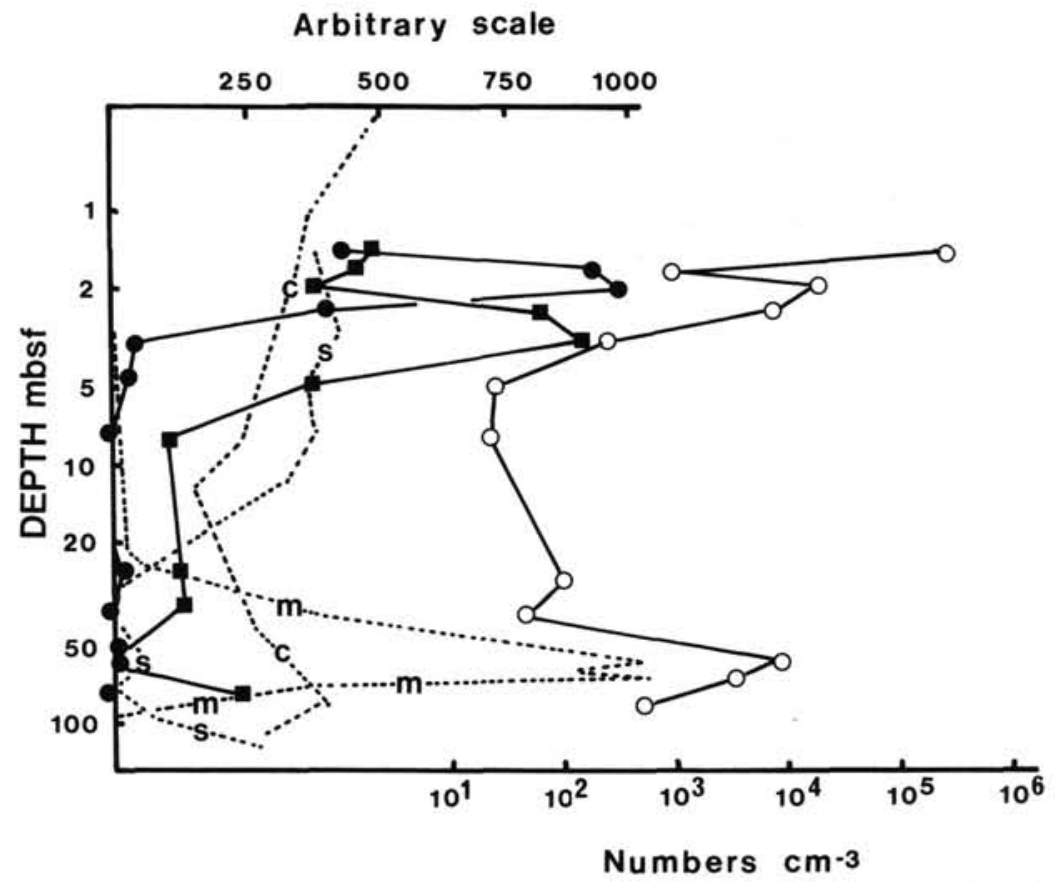

Figure 10. Profiles of total (PVS + AVS) potential sulfate-reduction activity (-1) $\left(\mathrm{nmol} / \mathrm{cm}^{3} / \mathrm{d}^{-1} \times 2000\right)$, potential methanogenic activity $\left(-\mathbf{n}, \mathrm{nmol} \mathrm{cm} \mathrm{cm}^{-3} \mathrm{~d}^{-1} \times\right.$ $5000)$, in-situ concentrations of organic carbon $(-.-C-., \% \times 100)$, (from Patience et al., [this volume]), sulfate $\left(--\mathrm{S}-\cdots, \mathrm{mmol} \mathrm{L}^{-1} \times 20\right)$, and methane (- - M- $\left.\mu \mathrm{L} / \mathrm{L}^{-1} / 25\right)$, from Suess, von Huene, et al., 1986), total culturable anaerobic count $(\mathrm{O}-\mathrm{O}), \mathrm{MPN}$ numbers $/ \mathrm{cm}^{-3}$ ).

trophic biomass, which was observed between 1.7 and $3.3 \mathrm{~m}$ (Table 2). In addition, heterotrophic potential (Fig. 8) decreased rapidly in this region. After methanogenesis had increased, the numbers of heterotrophic bacteria again increased (Fig. 10; Table 2). If this hypothesis is correct, then methane consumption by SRB (Iversen and Jørgensen, 1985) could account for a significant portion of the peak in sulfate reduction above methanogenesis and might explain the apparent contradiction of having methanogenesis without the presence of significant amounts of methane (Fig. 10). This stimulation in methanogenesis soon starts to become limited, reflecting the continued decrease in the heterotrophic bacteria that supply their substrates (Figs. 1 and 8 ). After about $7 \mathrm{~m}$, little bacterial activity takes place, total numbers of culturable anaerobic bacteria are low, as is the FDC (Figs. 2 and 10) and percentage of viability (Table 2). Thus, most of the organic carbon in this zone is predominantly unavailable to the bacteria. At about $60 \mathrm{~m}$ the concentration of organic carbon begins to increase, and there is an increase in total culturable anaerobic bacteria (Fig. 10), heterotrophic bacteria (Fig. 1), and heterotrophic potential (Fig. 8). At the same depth, there is a small increase in the concentration of sulfate and an equally small stimulation in sulfate reduction (Fig. 10). This sulfate reduction continues for about $10 \mathrm{~m}$ and possibly becomes sulfate-limited, which permits methanogenesis to develop once again at about $80 \mathrm{~m}$. Just above this increase in methanogenesis is a broad peak in methane, some of which may be used by the SRB higher up in the core, although this will be restricted because of limited sulfate. The stimulation of bacterial activity so deep within the sediment may be due to a combination of an increase in depositional carbon that had survived early diagenesis and chemical changes in the pore water from brine incursion. It is tempting to speculate that sulfate reduction should again increase below $80 \mathrm{~m}$, where sulfate concentrations are steadily increasing, and thus the bacterial interactions in the lower part of the hole should mirror the changes observed in the upper hole (Fig. 10), although much reduced in actual rates of activity.

Results from Hole $680 \mathrm{C}$ indicate essentially the same response pattern as Hole $681 \mathrm{C}$. As the deepest samples were only from 9.1 mbsf, trends are not as clear. Nevertheless, the succession of viable heterotrophs/nitrate utilizers to sulfate reducers to methanogens is similarly apparent (Table 2). Microbial numbers are generally higher, which is probably related to the much higher organic carbon concentration of approximately twice that in Hole $681 \mathrm{C}$ between 1.2 and $9.1 \mathrm{~m}$ (Patience et al., this volume). Sulfate-reduction rates are also higher $(3.3 \times$ greater at $2.0 \mathrm{~m}$; Fig. $9 \mathrm{G})$. Because sulfate concentrations are nearly $40 \%$ greater (approximately 22 $\mathrm{mM}$ ), the elevated sulfate-reduction rate is probably a reflection of both the increase in the availability of carbon and sulfate. Viable anaerobic heterotrophs (Fig. 9A), FDC (Fig. 9B), and organic carbon (data not shown) display a decrease with depth analagous to that in Hole 681C (Fig. 10), and there is a similar switch from sulfate reduction to methanogenesis in the continued presence of sulfate.

\section{SUMMARY}

This study has comprehensively demonstrated the presence and activity of bacteria to at least $80.2 \mathrm{mbsf}$, with subtle interactions among different bacterial groups that would not be anticipated from purely chemical data. Direct counts gradually decrease, with no indication of a more rapid decline in the deeper layers, and viability has been established at all depths sampled. Where numbers of viable bacteria and activity approach zero, the brine incursion has shown dramatically that further bacterial growth and activity can be stimulated in sediments approximately $1,000,000 \mathrm{yr}$ old (Suess, von Huene, et al., 1986). It is highly probable that bacteria continue to survive and maintain potential activity at deeper sediment 
layers, and therefore, have a profound effect on diagenesis. The high porosity of these sediment cores means that motile sediment bacteria, which are known to be mobile (Davidson and Fry, 1987), might possibly reach the deeper sediment layers by migration, although energy considerations make this unlikely. A principle aim for future studies in this area must be to establish the actual limit of penetration of the biosphere into the geosphere.

\section{ACKNOWLEDGMENTS}

We thank G. Eglinton, K. Kvenvolden, B. Julson, and M. Mefford for sample collection; W. J. Buckingham and J. A. Hodges for technical assistance, and J. Watson for computer assistance. This work was funded by a research grant (GR3/GST/02/248) from the Natural Environment Research Council, United Kingdom. We are grateful to the Ocean Drilling Program for providing samples from Leg 112.

\section{REFERENCES}

Alexander, M., 1965. Most-Probable-Number methods for microbial populations. In Black, C. A. (Ed.), Methods for Soil Analysis: Madison (Am. Soc. of Agronomy), 1477-1483.

Belyaev, S. S., and Ivanov, M. V., 1983. Bacterial methanogenesis in underground waters. In Hallberg, R. (Ed.), Environmental Geochem. Ecol. Bull., 35:273-280.

Bianchi, A., 1986. Heterotrophic bacterial types surviving in the Quaternary and upper Pliocene sediments of the Mahakam Delta. C. R. Acad. Sci., Paris (Ser. III), 303:449-451.

Colwell, R. R., 1979. Enumeration of specific populations by the Most-Probable-Number (MPN) method. In Costerton, J. W., and Colwell, R. R. (Eds.), Native Aquatic Bacteria: Enumeration, Activity and Ecology: Philadelphia (ASTM), ASTM STP 695:5661.

Connan, J., 1987. Biodegradation of crude oils in reservoirs. In Hill, E. C., Shennan, J. L., and Watkinson, R. J. (Eds.), Microbial Problems in the Offshore Oil Industry: Chichester (Wiley), 49-55.

Cruikshank, R., Duguid, J. P., Marmion, B. P., and Swain, R.H.A., 1975. Medical Microbiology, Vol. 2, The Practice of Medical Microbiology (12th Ed.): Edinburgh (Churchill Livingstone).

Davidson, A. M., and Fry, J. C., 1987. A mathematical model for the growth of bacterial microcolonies on marine sediment. Microb. Ecol., 13:31-45.

Davis, J. B., 1967. Petroleum Microbiology: Amsterdam (Elsevier).

Edenborn, H. M., Silverberg, N., Mucci, A., and Sundby, B., 1987. Sulfate reduction in deep coastal marine sediments. Mar. Chem., 21:329-345.

Fallon, R. D., Newell, S. Y., and Hopkinson, C. S., 1983. Bacterial production in marine sediments: will cell-specific measures agree with whole-system metabolism? Mar. Ecol. Prog. Ser., 11:119127.

Fry, J. C., 1988. Determination of biomass. In Austin, B. (Ed.), Methods in Aguatic Bacteriology: Chichester (Wiley), 27-72.

Goldhaber, M. B., and Kaplan, I. R., 1975. Controls and consequences of sulfate reduction rates in recent marine sediments. Soil Sci., 119(1):42-55.

Golterman, H. L., Clymo, R. S., and Ohnstad, M.A.M., 1978. Methods for Physical and Chemical Analysis of Freshwaters IBP 8 (2nd Ed.): Oxford (Blackwell).

Hagström, A., Larsson, U., Horstedt, P., and Normark, S., 1979. Frequency of dividing cells, a new approach to the determination of bacterial growth rates in aquatic environments. Appl. Environ. Microbiol., 37:805-812.

Hines, M. E., and Buck, J. D., 1982. Distribution of methanogenic and sulfate-reducing bacteria in nearshore marine sediments. Appl. Environ. Microbiol., 43:447-453.

Hippe, H., 1984. Maintenance of methanogenic bacteria. In Kirsop, B. E., and Snell, J. J. (Eds.), A Manual of Laboratory Methods: London (Academic), 69-81.

Hurley, M. A., and Roscoe, M. E., 1983. Automated statistical analysis of microbial enumeration by dilution series. J. Appl. Bacteriol., 55:159-164.
Iversen, N., and Jørgensen, B. B., 1985. Anaerobic methane oxidation rates at the sulfate-methane transition in marine sediments from Kattegat and Skagerrak (Denmark). Limnol. Oceanogr., 30(5):944-955.

Jannasch, H. W., and Taylor, C. D., 1984. Deep-sea microbiology. Annu. Rev. Microbiol., 38:487-514.

Jørgensen, B. B., 1979. A comparison of methods for the quantification of bacterial sulfate reduction in coastal marine sediments. I. Measurement with radiotracer techniques. Geomicrobiol. J., 1:11-28. 1983. Processes at the sediment/water interface. In Bolin, B., and Cook, R. B. (Eds.), The Major Biogeochemical Cycles and their Interactions: Chichester (Wiley), 477-515.

King, G. M., 1984. Metabolism of trimethylamine, choline, and glycine betain by sulfate-reducing and methanogenic bacteria in marine sediments. Appl. Environ. Microbiol., 48:719-725.

King, G. M., Klug, M. J., and Lovley, D. R., 1983. Metabolism of acetate, methanol, and methylated amines in intertidal sediments of Lowes Cove, Maine. Appl. Environ. Microbiol., 45:18481853.

Kristjansson, J. K., Schönheit, P., and Thauer, R. K., 1982. Different $K_{\mathrm{s}}$ values for hydrogen of methanogenic bacteria and sulfatereducing bacteria. Arch. Microbiol., 131:278-282.

Krumbein, W. E., 1983. Microbial Geochemistry: Oxford (Blackwell).

Lein, A. Y., Namsaraev, G. B., Trotsyuk, V. Y., and Ivanov M. V., 1981. Bacterial methanogenesis in Holocene sediments of the Baltic Sea. Geomicrobiol. J., 2(4):299-315.

Lochte, K., and Turley, C. M., 1988. Bacteria and cyanobacteria associated with phytodetritus in the deep sea. Nature, 333:67-69.

Macfarlane, G. T., and Herbert, R. A., 1984. Dissimilatory nitrate reduction and nitrification in estuarine sediments. J. Gen. Microbiol., 130:2301-2308.

Moriarty, D.J.W., White, D. C., and Wassenberg, T. J., 1985. A convenient method for measuring rates of phospholipid synthesis in seawater and sediments: its relevance to the determination of bacterial productivity and the disturbance artifacts introduced by measurements. J. Microb. Meth., 3:321-330.

Nedwell, D. B., 1984. The input and mineralization of organic carbon in anaerobic aquatic sediments. In Marshall, K. C. (Ed.), Advances in Microbial Ecology: New York (Plenum), 7:93-131.

Newell, S. Y., and Fallon, R. D., 1982. Bacterial productivity in the water column and sediments of the Georgia (U.S.) coastal zone: estimates via direct counting and parallel measurement of thymidine incorporation. Microbial Ecol., 8:333-346.

Oremland, R. S., and Polcin, S., 1982. Methanogenesis and sulfate reduction: competitive and non-competitive substrates in estuarine sediments. Appl. Environ. Microbiol., 44:1270-1276.

Oremland, R. S., Marsh, L. M., and Polcin, S., 1982. Methane production and simultaneous sulfate reduction in anoxic salt marsh sediments. Nature, 296:143-145.

Parkes, R. J., and Buckingham, W. J., 1986. The flow of organic carbon through aerobic respiration and sulfate reduction in inshore marine sediments. In Megusar, F., and Gantar, M. (Eds.), Proc. 4th Int. Symp. Microbial Ecol., 617-624.

Parkes, R. J., and Taylor, J., 1985. Characterization of microbial populations in polluted marine sediments. J. Appl. Bacteriol., 59:155S-173S.

Pettipher, G. L., 1983. The Direct Epifluorescence Filter Technique for the Rapid Enumeration of Micro-organisms: Letchworth (Research Studies Press).

Pfennig, N., Widdel, F., and Truper, H. G., 1981. The dissimilatory sulfate-reducing bacteria. In Starr, M. P., Stolp, H., Truper, H. G., Balows, A., and Schlegal, H. G. (Eds.), The Prokaryotes: New York-Berlin-Heidelberg (Springer-Verlag), 1:926-940.

Pfennig, N., and Biebl, H., 1981. The dissimilatory sulfur-reducing bacteria. In Starr, M. P., Stolp, H., Truper, H. G., Balows, A., and Schlegal, H. G., (Eds.), The Prokaryotes: New York-BerlinHeidelberg (Springer-Verlag), 1:941-947.

Postgate, J. R., 1979. The Sulphate-Reducing Bacteria: Cambridge (Cambridge Univ. Press).

Revsbech, N. P., Sorensen, J., and Blackburn, T. H., 1980. Distribution of oxygen in marine sediments measured with microelectrodes. Limnol. Oceanogr., 25:403-411. 
Rheinheimer, G., 1985. Aguatic Microbiology (3rd Ed.): Chichester (Wiley).

Rice, A. L., Biller, D.S.M., Fry, J. C., John, A.W.G., Lampitt, R. S., Mantoura, R.F.C., and Morris, R. J., 1986. Seasonal deposition of phytodetritus to the deep seafloor. Proc. Roy. Soc. Edin., 88B:265-279.

Schönheit, P., Kristjansson, J. K., and Thauer, R. K., 1982. Kinetic mechanism for the ability of sulfate reducers to outcompete methanogens for acetate. Arch. Microbiol., 132:285288.

Senior, E., Lindström, E. B., Banat, I. M., and Nedwell, D. B., 1982. Sulfate reduction and methanogenesis in the sediment of a salt marsh on the east coast of the United Kingdom. Appl. Environ. Microbiol., 43:987-996.

Somerville, C. C., Mont, C. A., and Spain, J. C., 1985. Modification of the ${ }^{14} \mathrm{C}$ Most-Probable-Number method for use with non-polar and volatile substrates. Appl. Environ. Microbiol., 49(3):711-713.

Sorokin, Yu. I., 1962. Experimental investigation of bacterial sulfate reduction in the Black Sea using ${ }^{35} \mathrm{~S}$. Microbiology, 31:329-335.

Suess, E., von Huene, R., et al., 1986. Proc. ODP, Init. Repts, 112: College Station, TX (Ocean Drilling Program).

Tarafa, M. E., Whelan, J. K., Oremland, R. S., and Smith, R. L., 1987. Evidence for microbiological activity in Leg 95 (New Jersey Transect) sediments. In Poag, C. W., Watts, A. B., et al., Init. Repts. DSDP, 95: Washington (U.S. Govt. Printing Office), 635640.
Tsou, J. L., Hammond, D., and Horowitz, R., 1973. Interstitial water studies, Leg 15. Study of $\mathrm{CO}_{2}$ released from stored deep sea sediments: DSDP Leg 15. In Heezen, B. C., MacGregor, I. D., et al., Init. Repts DSDP, 20: Washington (U.S. Govt. Printing Office), 851-863.

van Es, F. B., and Meyer-Reil, L. A., 1982. Biomass and metabolic activity of heterotrophic marine bacteria. In Marshall, K. C. (Ed.), Advances in Microbial Ecology: New York (Plenum), 6:111-170.

Whelan, J. K., Oremland, R., Tarafa, M., Smith, R., Howarth, R., and Lee, C., 1985. Evidence for sulfate-reducing and methaneproducing organisms in sediments from Sites 618, 619, and 622. In Bouma, A. H., Coleman, J. M., Meyer, A. W., et al., Init. Repts DSDP, 96: Washington (U.S. Govt. Printing Office), 767-775.

Winfrey, M. R., and Ward, D. M., 1983. Substrates for sulfate reduction and methane production in intertidal sediments. Appl. Environ. Microbiol., 45:193-199.

Zeikus, J. G., 1983. Metabolic communication between biodegradative populations in nature. In Slater, J. H., Whittenbury, R., and Wimpenny, J.W.T. (Eds.), Microbes in Their Natural Environments: Cambridge (Cambridge Univ. Press), 423-462.

Date of initial receipt: 1 August 1988

Date of acceptance: 5 July 1989

Ms 112B-161 